\title{
State policies and upgrading in global value chains: A systematic literature review
}

\author{
Valentina De Marchi ${ }^{1}$ and \\ Matthew Alford ${ }^{2}$ \\ ${ }^{1}$ Department of Economics and Management \\ 'Marco Fanno', University of Padova, \\ 35123 Padova, Italy; ${ }^{2}$ Alliance Manchester \\ Business School, University of Manchester, \\ Manchester, UK \\ Correspondence: \\ V De Marchi, Department of Economics and \\ Management 'Marco Fanno', University of \\ Padova, 35123 Padova, Italy \\ e-mail: valentina.demarchi@unipd.it
}

\begin{abstract}
This paper examines the role of state policymaking in a context of global value chains (GVCs). While the literature acknowledges that states matter in GVCs, there is little understanding of how they matter from a policy perspective. We address this tension between theory and practice by first delineating the state's facilitator, regulator, producer and buyer roles. We then explore the extent to which corresponding state policies enable or constrain the following policy objectives: GVC participation; value capture; and social and environmental upgrading. We do so via a systematic review of academic GVC literature, combined with analysis of seminal policy publications by International Organizations. Our findings indicate that state policymakers leverage facilitative strategies to achieve GVC participation and enhanced value capture; with regulatory and public procurement mechanisms adopted to address social and environmental goals. Mixed results also emerged, highlighting tensions between policies geared towards economic upgrading on the one hand, and social and environmental upgrading on the other. Finally, we suggest that effective state policies require a multi-scalar appreciation of GVC dynamics, working with multiple and sometimes competing stakeholders to achieve their developmental objectives.
\end{abstract}

Journal of International Business Policy (2022) 5, 88- I। I.

https://doi.org/ | 0.1057/s422 14-02 I-00107-8

Keywords: state; global value chains; policies; global production networks; policymakers; downgrading; upgrading

The online version of this article is available Open Access

\section{INTRODUCTION}

Global value chain (GVC) and global production network (GPN) frameworks are being increasingly adopted by academics and practitioners as a means to understand the global organization of industries and their developmental impact (De Marchi et al., $2020)^{1}$. Central to these frameworks is the attention given to nonequity-linked trade governed by powerful multinationals - socalled 'global lead firms', who are driving the development of industries worldwide (Gereffi, 2014; Gereffi et al., 2005). These profound changes in the structure of the global economy are heavily impacting the trade and industrial policy domain, which is
Received: 30 August 2019

Revised: 3 March 2021

Accepted: 8 March 2021

Online publication date: 12 May 2021 
becoming ever more complex. On the one hand, participation in global lead firm-driven GVCs may facilitate learning and enhance the development potential for supplier firms and territories, particularly in developing-country contexts (Gereffi, 2018). On the other hand, the ability to appropriate value and upgrade through GVC participation is not straightforward, considering diverse stakeholder interests and power asymmetries between global lead firms and their fragmented supplier base (Alford \& Phillips, 2018; Blažek, 2016; Ponte \& Ewert, 2009).

Against the backdrop of a highly liberalized global economy, early GVC studies observed that the role of nation-states was largely restricted to a passive, facilitative role, oriented towards attracting lead-firm investment (Gereffi, 1994). At that time, major international organizations (IOs) including the IMF and World Bank advanced a highly liberal interpretation of state roles, reflected most acutely in the 'Washington Consensus', which were restricted to privatization, de-regulation, and promoting the free flow of cross-border trade (Wade, 2003; Mayer \& Gereffi, 2019). More recent academic studies, however, propose a more interventionist interpretation of nation-states, who are deemed to play an active role in mediating GVCs to protect national policy interests (Mayer \& Phillips, 2017). This has given way to more robust theorizing of state roles in GVC/GPN literature (Alford \& Phillips, 2018; Horner, 2017; Horner \& Alford, 2019; Smith, 2015), which include facilitative, regulatory, producer, and buyer functions. From a policy perspective, this more interventionist academic interpretation of states is reflected in an emerging consensus (including among certain branches of more liberally oriented IOs such as the World Bank and OECD) that state policymaking in a GVC order entails a shift in the design and development of policy interventions for local development (ILO, 2006, 2015; UNIDO, 2002, 2011, 2015; UNCTAD, 2020).

Accordingly, in recent years, a core focus of both academic and policy debates has been on the role nation states can and should play in mediating GVCs (Alford \& Phillips, 2018), to ensure more equitable and sustainable distribution of gains from GVC participation (Ponte \& Ewert, 2009); and support the development of supplier capabilities (Guerrieri \& Pietrobelli, 2004; Pietrobelli \& Puppato, 2016; Pietrobelli \& Staritz, 2013, 2018). How to conceive and develop such state policies in order to maximize local value creation and learning opportunities associated with GVC participation is therefore a key policy issue. This is particularly pertinent in relation to improving social and environmental conditions in GVCs (Dermawan \& Hospes, 2018), given these objectives often conflict with economic imperatives (De Marchi, Di Maria, Krishnan, \& Ponte, 2019; Krishnan, 2017). However, such policy objectives are complex - needing to balance attracting global lead firm investment and regulating them, to ensure the local accumulation of wealth and knowledge through GVC participation (Alford \& Phillips, 2018; Morris \& Staritz, 2019). To address these issues, the paper asks: Which policy initiatives, relating to the four state roles (facilitator, regulator, producer, buyer), support (or constrain) economic, social, and environmental upgrading in GVCs? In what contexts are those initiatives likely to be implemented?

This paper addresses these challenges via a systematic review of the literature on national policy-making in a GVCs/GPNs context drawing on the state typology by Horner (2017). Such an effort is particularly relevant, given existing GVCs/ GPNs frameworks are often misused in the policy arena, causing confusion on how these approaches can be meaningfully applied (Gereffi, 2019; Pietrobelli \& Staritz, 2018); and the role of the state in GVCs/GPNs literatures requires further theorization (Smith, 2015). Indeed, scholarly attention has predominantly focused on the state's role in facilitating or regulating GVC participation (Azmeh, 2014a, b; Curran et al., 2019; Pickles et al., 2015), while less attention has been devoted to its producer or buyer roles (Horner, 2017; Horner \& Alford, 2019). Accordingly, this paper builds on recent acknowledgement that states matter in GVCs (Alford \& Phillips, 2018; Horner \& Alford, 2019), by providing a systematic account of how they matter from a policy perspective. We do so by operationalizing the state's facilitator, regulator, producer, and buyer roles, and exploring the extent to which different state initiatives enable GVC participation, value capture, and associated upgrading outcomes. In doing so, we extend seminal work by Gereffi and Sturgeon (2013) - by broadening the empirical scope of GVC research; and Pietrobelli and Staritz (2018) - by focusing on national and sub-national policy-makers, as opposed to IOs and donors.

The paper is organized as follows. Section two outlines the principal upgrading and GVC-oriented concepts investigated in the paper. Section three provides a description of the methodology. 
Section four presents the evidence emerging from the systematic literature review. Here, we first report on the results of our content analysis, examining the extent to which different state initiatives address GVC-oriented policy objectives and associated upgrading outcomes. Then, we compare cases of upgrading and downgrading to develop insights for the effective design and implementation of GVC-oriented policies. Section five concludes with lessons learned.

\section{UPGRADING AND GVC-ORIENTED STATE POLICIES}

Over the past few decades, the organization of industries and functioning of national economies have been profoundly altered. Production has been unbundled, meaning service and manufacturing activities are increasingly carried out via global inter-firm networks that fall outside the boundaries of a firm (Feenstra, 1998; Mudambi et al., 2018). Multinationals have increasingly externalized activities to maximize efficiency gains, to the point that some firms - the so-called 'global buyers' (Gereffi, 1994) or 'global factories' (Buckley, 2004; Buckley \& Ghauri, 2004) - are only responsible for pre- or post-production activities, without directly engaging in production at any stage (Strange \& Humphrey, 2018). Such powerful lead firms coordinate activities of 'complex and dynamic economic networks made up of inter-firm and intrafirm relationship(s)' (Gereffi, 2014, p. 10) - spanning between market and hierarchy - termed "global value chains" (Bair \& Gereffi, 2001; Gereffi, 1999) or "global production networks" (Coe et al., 2004; Henderson et al., 2002).

Particularly for developing countries, the proliferation of GVCs has represented new, important channels for industrial development and knowledge access (Pietrobelli \& Rabellotti, 2011), helping to facilitate value-adding activities and a 'move up the value chain' (Ponte \& Ewert, 2009: 1638) termed 'upgrading' in GVC literature. Upgrading refers to the strategies that firms, countries, or regions implement to move toward higher valueadded activities and increased value capture (Gereffi, 2005), and the learning opportunities arising from the GVC participation (Giuliani et al., 2005; Pietrobelli \& Rabellotti, 2011). Different forms of economic upgrading have been identified (Fernandez-Stark \& Gereffi, 2019; Frederick \& Staritz, 2011; Humphrey \& Schmitz, 2002). The two 'basic' forms are product (moving toward new or more sophisticated products) and process (introducing new or improved methods of production) upgrading. Functional upgrading entails the ability to shift towards more value-added activities, such as from basic assembly to more advanced forms of 'full package' supply. Though more challenging, this latter form of upgrading provides local suppliers the possibility to generate and sustain value capture over an extended timescale. Other forms of GVC upgrading entail strengthening backward and forward linkages (supply chain upgrading) and serving new markets or specializing in a new industry (channel and inter-chain upgrading, respectively).

In the last decade, the concept of upgrading ${ }^{2}$ has been extended to cover social and environmental aspects (De Marchi et al., 2020), following increased attention to the adverse impact of globalization on developing economies. Social upgrading is anchored in the International Labor Organization (ILO) framework on 'decent work', and defined as the improvement in the rights and entitlements of workers and enhanced quality of employment (Barrientos, Gereffi, \& Rossi, 2011a, Barrientos, Mayer, Pickles, \& Posthuma, 2011b; Gereffi \& Lee, 2016). Social upgrading can be further delineated into two components: measurable standards, which refer to aspects of working conditions that are more easily quantifiable (e.g., wage levels, working hours, employment type); and enabling rights, which are more difficult to measure and refer to complex bargaining processes, such as freedom of association, the right to union representation, non-discrimination and collective bargaining, voice and empowerment (Barrientos et al., 2011a, b). Environmental upgrading entails 'the process by which economic actors move towards a production system that avoids or reduces environmental damage from their products, processes, or managerial systems' (De Marchi et al., 2019: 312). It can be further delineated by process improvements (i.e., eco-efficiency achieved by reorganizing production systems or using a superior technology); product improvements (i.e., developing more sophisticated and environmentally friendly product lines); and organizational improvements (i.e., enhancing a firm's way of doing business, often related with meeting international standards and certifications) (De Marchi et al., 2019).

Several studies have found upgrading to be a highly uneven process, wherein the potential of learning and growth does not always materialize; up and down-grading often coexist (Blažek, 2016; Ponte \& Ewert, 2009) and trade-offs between 
economic, social, and environmental upgrading play out (Lee \& Gereffi, 2015; Milberg \& Winkler, 2011; Morris et al., 2016). The possibility for firms and territories to effectively learn and develop from GVC participation depends on the type of coordination mechanism implemented by lead firms and their strategic interests (e.g., Humphrey \& Schmitz, 2002; Kaplinsky \& Morris, 2001); the absorptive capabilities and technological endowment of the firms (e.g., Morrison et al., 2008; Pietrobelli \& Rabellotti, 2011); and the role of the state and institutional context in which local firms are embedded (Coe et al., 2008; Henderson et al., 2002).

Focusing on the latter aspect, the importance of effective policy-making is motivated by the presence of specific market and coordination failures that characterize GVCs (Pietrobelli \& Staritz, 2018). An increasing share of GVCs/GPNs studies have explored GVC-oriented policies, i.e., policies that account for the global interconnections among firms and are aimed at improving access to GVCs or capturing higher value shares ${ }^{3}$. As stated by Pietrobelli and Staritz (2018), GVC-oriented policies are quite distinct from more general policies aimed at supporting private sector development. A key specificity is that GVC-oriented policies need to connect and leverage lead firms, accounting for their bargaining power over a fragmented supplier base (Dallas et al., 2019). This requires a different approach relative to industrial policies prevalent in the 1980s and 1990s that focused on raising barriers for developing countries (Morris \& Staritz, 2019), toward a multi-scalar perspective, accounting for sector specificities, inter-firm relations, and localized value-creation. According to Pietrobelli and Staritz (2018), GVC-oriented policies are broadly aimed at achieving the following objectives - (i) supporting participation in GVCs, to improve supplier firms' ability (especially those based in developing countries) to meet the sourcing demands of global buyers, that are often complex, costly, and require linkages to complementary expertise; (ii) enhancing the capture of value produced therein, accounting for power asymmetries between lead firms and supplier firms', potentially hindering the latter's ability to capture sufficient gains from GVC participation; and/or (iii) improving labor and environmental conditions (see also IILS, 2006, ILO, 2015).

In early GVC research, and perhaps reflecting the pervasive global economic reality at the time, Gereffi (1994: 10) observed that governments occupied a passive role, facilitating export-oriented development. A dominant perspective was that state-policy was restricted to promoting an attractive business environment both for global lead firms and local suppliers seeking to integrate into GVCs (Horner \& Alford, 2019). This was reflected in the World Trade Organization's (WTO) establishment in 1994, which significantly shrank the developmental policy space afforded to states (Wade, 2003). It is fair to say that other major International Organizations (IOs) including branches of the OECD and World Bank subsequently advanced this liberal interpretation of state roles vis a vis GVCs, wherein the role of states is limited to "promoting well-functioning GVCs and minimizing trade "friction" at borders (i.e., fewer restraints and regulations)' (Mayer \& Gereffi, 2019: 578).

Recent observations suggest a more interventionist interpretation of nation-states in relation to GVCs, wherein states might play a broader array of roles, to mediate private interests in order to strengthen local development outcomes (Mayer \& Phillips, 2017). National policies have been advocated particularly in the realm of social and environmental upgrading, following increasing recognition that lead firms might not be sufficiently committed or able to address such complex issues in their value chains (ILO, 2015; Hossain, 2019; Riisgaard, LundThomsen, \& Coe, 2019). Over the past decade, GVC/GPN research highlights that addition to the state's role in actively facilitating GVCs, they can also play a central role in regulating firm activity; producing goods and services destined for GVCs; and buying products through public procurement (Alford \& Phillips, 2018; Horner, 2017; Horner \& Alford, 2019; Smith, 2015). This more interventionist interpretation is reflected also in seminal IO publications on GVCs and decent work by the International Labor Organization (ILO) (2006, 2015), and other agencies calling for more proactive state approaches to GVCs, in order to achieve economic competitiveness, regional and national development (see also UNCTAD, 2020; UNIDO, 2002, 2011, 2015).

Building on the previous discussion, this article focuses specifically on national and sub-national state policy-makers (i.e., regional, provincial, or city-level), and the extent to which they can influence the functioning of GVCs and ability of domestic firms to participate, capture value, and upgrade (Alford \& Phillips, 2018; Horner, 2017; Horner \& Alford, 2019). In this context, we adopt Horner's (2017) classification, who suggests the 
state can act as facilitator - by supporting local firms to participate and upgrade in GVCs, through policies such as tax incentives, subsidies, trade policies, and R\&D incentives; as regulator - by constraining the activities of global lead firms or of local suppliers through quality controls, standards implementation, labor regulation, state marketing boards, and price control mechanisms; as producer - by directly engaging in state-owned production activities in competition with other private firms within GVCs; and/or as buyer - by directly procuring products and services via stateled value chains, which may comprise distinct economic, social, and environmental standard requirements (Alford \& Phillips, 2018; Horner, 2017; Horner \& Alford, 2019; Mayer \& Phillips, 2017). Which policies, relating to each of these state roles, are more likely to support (or constrain) economic, social, and environmental upgrading? In what contexts are those initiatives likely to be implemented?

\section{METHODOLOGY}

For the purpose of this study, we conduct a systematic literature review (Tranfield et al., 2003) of the evidence emerging from the academic GVC/ GPN literature, describing the impact of specific

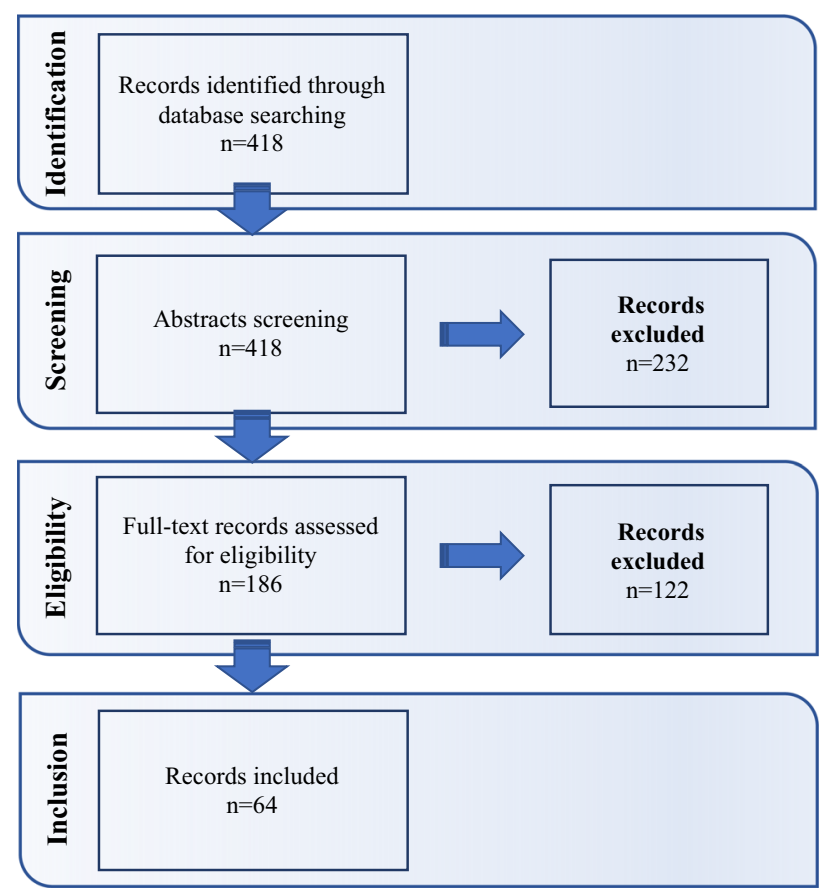

Figure 1 The paper selection process. state initiatives on GVC-oriented policy objectives and upgrading.

A step-wise approach has been adopted to collect materials following the PRISMA method (Liberati et al., 2009) as summarized in Figure 1. The literature review comprises English-speaking peerreviewed articles or book chapters that are present in the Scopus search engine, relating to the 'Social Science', 'Business, Management and Accounting' or 'Economics, Econometrics and Finance' subject areas. In order to identify the contributions relevant for the scope of our analysis, we used a combined search string which included words having the root 'polic' (i.e., all the words: policy, policies, policy-making, policymaking) and either 'global value chain' or 'global production network'. In total, 418 contributions have been identified using this selection process ${ }^{4}$. To ensure we identified only contributions that fit with the purpose of our analysis, an abstract screening was performed, based on three eligibility criteria:

(1) Focusing on state policies We included only contributions that clearly focused on specific state interventions and policy instruments (e.g., R\&D policies, tariffs, public procurement...), excluding articles and chapters that were simply suggesting policy implications or advocating for policy interventions as a discussion of their main results.

(2) Adopting a GVC (or GPN) approach We therefore included only contributions that were clearly referring to at least one of the key pillars of the GVCs/GPNs literatures, i.e., governance, upgrading, power, value capture, embeddedness (Coe et al., 2004; Gereffi, 2019), and focusing on networks of firms related by non-proprietary ties, each being responsible for different yetinterrelated activities. Contributions taking a single firm perspective (i.e., MNEs and their subsidiaries) or the country-level (without considering for differences in industries) were excluded.

(3) Being empirical We only included contributions providing enough information to understand the policy interventions implemented and local up/downgrading dynamics observed. Accordingly, contributions that discussed specific policy interventions (e.g., policies to increase innovation capabilities), or policies for specific industries or countries and regions (e.g., the mining industry in Colombia) were included. Purely theoretical articles or articles not 
including enough information to understand policy in a GVC context were excluded.

Overall, 232 articles were excluded because they did not meet one or more of these criteria. In case the abstract was not explicit enough to understand if these criteria were met, we performed a fullarticle screening. Following this additional screening, a further 122 manuscripts were excluded adopting the same three criteria presented above (see Figure 1); because they were not in English; or it was not possible to access the full text. Finally, 64 contributions were considered in the analysis and are listed in Table A. 1 in the Appendix ${ }^{5}$. Table 3 breaks down the contributions reviewed by stage of economic development and sector ${ }^{6}$. As emerges from those tables, the majority of contributions are focused on complex products or traditional manufacturing sectors (32.8 and $26.9 \%$, respectively); $17.9 \%$ are focused on natural resource-based GVCs; and only $6 \%$ on services. Almost half of the contributions examine GVCs based in upper-middle countries $(46.3 \%$ of the contributions analyzed), lower-middle and high-income countries are covered by one-quarter of the studies (26.9 and $25.4 \%$, respectively); with relatively fewer studies focused on low-income countries (10.4\%). As far as upgrading dynamics are concerned, economic upgrading is reported in $68.7 \%$ of the contributions analyzed (38.8\% on downgrading); social upgrading in $19.4 \%$ (14.9\% reporting on downgrading dynamics); with environmental upgrading the least addressed $(9.0 \%$ of the cases reporting upgrading and $7.5 \%$ downgrading). The subsequent discussion will delve deeper into these observations, in relation to each of the four state roles.

Such contributions have been carefully reviewed and coded using the software MaxQDA to provide a systematic and quantitative analysis of the key evidence emerging. A deductive approach to coding has been adopted, accounting for potential within-study bias and expectancy bias that might affect the (systematic) literature review (Durach et al., 2017). The coding process was based on the categories discussed in the theoretical section. Based on the analysis by Horner (2017), we identified different policies connected to a state's facilitator, regulator, producer, and buyer roles. Table 1 identifies exemplary contributions reporting GVC-oriented policies corresponding with these state roles. Following classification provided by Pietrobelli and Staritz (2018), we categorize contributions by the following four policy objectives: (i) enhance GVC participation; (ii) increase value-capture; (iii) improve social conditions; (iv) improve environmental conditions. ${ }^{7}$ Classifications provided by Barrientos et al. (2011a, b), De Marchi et al. (2019) and Fernandez-Stark and Gereffi (2019) guided the coding of upgrading. Tables 2, 3, and 4 report the quantitative analysis performed, in relation to the four state roles analyzed. Table 2 highlights how often, within the sample of academic contributions analyzed, each state role has been oriented toward the four policy objectives discussed above. Table 3 reports on the empirical context of the analysis and Table 4 the different upgrading outcomes.

A key challenge relating to systematic literature reviews is their potential to overlook important contributions which fall outside the selection criteria, and yet may be central to the debate, thus driving sampling bias (Durach et al., 2017). Accordingly, while the quantitative analysis is grounded on academic papers identified via the aforementioned approach, the discussion of such results is also informed by theoretical contributions and relevant gray literature. In particular, to ensure important insights from the gray literature were not overlooked (including seminal IO publications) ${ }^{8}$, we merged multiple strategies. First, we searched for IO publications within the reference lists of articles identified via the systematic review described above. Second, we searched IO websites to scan for relevant publications. Third, we drew upon publications deemed seminal in the academic literature that specifically address the role of IOs for GVC development (Gereffi, 2019; Mayer \& Gereffi, 2019). Based on this multi-faceted approach, we identified key landmark IO publications ${ }^{9}$, which have been used to frame the empirical analysis and concluding discussion.

\section{STATES POLICIES AND UPGRADING AND DOWNGRADING TRAJECTORIES IN GVCS}

\begin{abstract}
State as Facilitator
As reflected in Table 2, in line with Horner (2017), the analysis indicates that the facilitator role has been by far the most addressed in GVCs/GPNs studies. This is further demonstrated by the fact that major IOs, including the WTO (2019; Elms \& Low, 2013), UNCTAD $(2013,2017,2020)$ and the World Bank (2016, 2020; Cattaneo et al., 2013) all contain trade policy and economic development
\end{abstract}


Table 1 GVC-oriented policies in the sample analyzed

Exemplary contributions

Facilitator

Incentives

Trade facilitations

Services

Knowledge infrastructure

Infrastructure

Regulator

Regulatory framework

Protective measures

Producer

Direct ownership

Buyer

Public procurement
69 (incentives for innovation in China),

196 (incentives to develop wind and solar power industries, cross-country comparison)

301 (trade incentives and labor standards in apparel),

199 (China-Vietnam's textile and garment industry trade facilitations)

13 (services to increase Rwanda coffee farmers capabilities and bargaining power);

523 (supporting offshore service sector in the Philippines)

13 (services to increase Rwanda coffee farmers capabilities),

314, 517 (supporting innovation at Penang Export Hub, Malaysia)

105 (growth corridors in Tanzania, Namibia, Zambia and Zimbabwe),

49 (development of Chongqing notebook computer manufacturing cluster)

162 (regulating IP regimes in UK TV broadcasting industry),

190 (social standards in the garment industry, India)

69 (to support development of innovation in China),

313 (to support development of new energy vehicles industry in China)

13 (state-owned production capacity to support higher value added, coffee industry in Rwanda), 527 (state-owned firm and development of liquid crystal display industry, China)

162 (buying local formats to support capabilities development, UK TV broadcasting industry) 315 (strengthening social and environmental standards, furniture industry in Mexico)

Note Examples of papers describing each specific GVC-oriented policy, using the codes reported in Table A.1.

Table 2 GVC-oriented policies, considering for different policy objectives

\begin{tabular}{|c|c|c|c|c|}
\hline & $\begin{array}{l}\text { Targeting access } \\
\text { and integration }\end{array}$ & $\begin{array}{l}\text { Targeting } \\
\text { value capture }\end{array}$ & $\begin{array}{l}\text { Targeting better } \\
\text { social conditions }\end{array}$ & $\begin{array}{l}\text { Targeting environmenta } \\
\text { sustainability }\end{array}$ \\
\hline Facilitator & $\circ \bullet \bullet$ & $\bullet \bullet \bullet$ & ০৫ & ০০০ \\
\hline Incentives & $\bullet \bullet \bullet$ & $\bullet \bullet \bullet$ & ০০০ & ০০০ \\
\hline Incentives to local firms & $\bullet \bullet \bullet$ & $\bullet \bullet \bullet$ & & \\
\hline Incentives to foreign firms & $\bullet \bullet \bullet$ & $\bullet \bullet \bullet$ & $\circ \circ \bullet$ & \\
\hline Trade facilitations & $\bullet \bullet \bullet$ & $\circ \bullet \bullet$ & ০• & \\
\hline Services & $\circ \bullet \bullet$ & $\bullet \bullet \bullet$ & 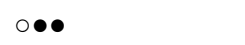 & ০॰ \\
\hline Knowledge infrastructure & $\bullet \bullet \bullet$ & $\bullet \bullet \bullet$ & ০০০ & \\
\hline Infrastructure building & $\bullet \bullet \bullet$ & $\bullet \bullet \bullet$ & ০॰ & ০০০ \\
\hline Regulator & $\circ \bullet \bullet$ & $\circ \bullet \bullet$ & ০॰ & ০॰ \\
\hline Regulatory framework & $\circ \bullet \bullet$ & $\circ \bullet \bullet$ & $\circ \bullet \bullet$ & ০॰ \\
\hline Protective measures & $\circ \bullet \bullet$ & $\circ \bullet \bullet$ & ০• & ০৫ \\
\hline Producer & $\bullet \bullet \bullet$ & $\bullet \bullet \bullet$ & $\circ \circ \bullet$ & ০॰ \\
\hline Buyer & $\bullet \bullet \bullet$ & $\bullet \bullet \bullet$ & ০॰ & 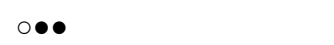 \\
\hline
\end{tabular}

Note $\bullet \bullet \bullet=$ major relevance, $\circ \bullet \bullet=$ significant relevance, $\circ \circ \bullet=$ moderate relevance, $\circ \circ \circ=$ minor relevance, empty $=$ marginal relevance. Relevance is calculated considering the incidence of records reporting on that objective, within those reporting about the policy reported in row.

Source Author's own elaboration

recommendations emphasizing the state's facilitator role.

Very often, these come in the form of trade agreements at bilateral (e.g., US-Vietnam - Ngo, 2017) or regional levels (e.g., the Africa Growth and Opportunity Act - Aberg \& Becker, 2019), aimed at both improving access to GVCs and, to a lesser extent, supporting value-added activities. Interestingly, such arrangements are also often used to support the achievement of social outcomes, rather than solely economic. The US-Cambodia Bilateral Textile Trade Agreement, for example, grants an increased garments export quota, in exchange for compliance with the ILO Better Factories project 
Table 3 GVC-oriented policies in the sample, considering for industries and countries analyzed

\begin{tabular}{|c|c|c|c|c|c|c|c|c|}
\hline & \multicolumn{4}{|c|}{ Countries } & \multicolumn{4}{|c|}{ Industries } \\
\hline & $\begin{array}{l}\text { Low } \\
\text { income }\end{array}$ & $\begin{array}{l}\text { Lower- } \\
\text { middle } \\
\text { income }\end{array}$ & $\begin{array}{l}\text { Upper- } \\
\text { middle } \\
\text { income }\end{array}$ & $\begin{array}{l}\text { High } \\
\text { income }\end{array}$ & Services & $\begin{array}{l}\text { Natural } \\
\text { resource } \\
\text { based }\end{array}$ & $\begin{array}{l}\text { Complex } \\
\text { products }\end{array}$ & $\begin{array}{l}\text { Traditional } \\
\text { manufacturing }\end{array}$ \\
\hline Facilitator & ০০ & $\circ \diamond \bullet$ & 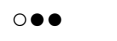 & ০• & & $০ ০ ০$ & $\circ \bullet \bullet$ & ০• \\
\hline Incentives & 000 & ০০০ & 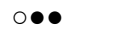 & ০• & & & $\circ \bullet \bullet$ & ০০০ \\
\hline Trade facilitations & ০॰ & 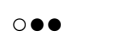 & $\circ \bullet \bullet$ & ০• & & & ০॰ & 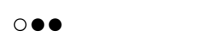 \\
\hline Services & ০• & $\circ \circ \bullet$ & ০• & ০॰ & ০০০ & ০৫ & ০॰ & ০॰ \\
\hline Knowledge infrastructure & & ০০ & $\bullet \bullet \bullet$ & ০• & ০০ & & $\circ \bullet \bullet$ & \\
\hline Infrastructure building & 000 & ০৫ & $\circ \bullet \bullet$ & ০• & & ০০০ & ০• & ০০০ \\
\hline Regulator & & ০• & $\circ \bullet \bullet$ & ০• & & ০৫ & ০• & ০• \\
\hline Regulatory framework & & ০॰ & $\bullet \bullet \bullet$ & ০• & & ০๑ & ০॰ & ০॰ \\
\hline Protective measures & & ০॰ & 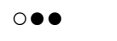 & ০॰ & & ০॰ & 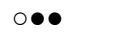 & ০॰ \\
\hline Producer & ০• & ০০ & $\circ \bullet \bullet$ & & ০০ & ০০ & $\circ \bullet \bullet$ & ০০ \\
\hline Buyer & & & $\bullet \bullet \bullet$ & $\circ \bullet \bullet$ & ০৫ & $\circ \circ \bullet$ & $\circ \bullet \bullet$ & ০• \\
\hline Overall & ০০০ & $\circ \diamond \bullet$ & $\bullet \bullet \bullet$ & ০• & & $\circ \diamond \bullet$ & $\circ \bullet \bullet$ & ০• \\
\hline
\end{tabular}

Note $\bullet \bullet=$ major occurrence, $\circ \bullet \bullet=$ significant occurrence, $\circ \circ \bullet=$ moderate occurrence, $\circ \circ \circ=$ minor occurrence, empty $=$ marginal occurrence . Occurrence is calculated considering the incidence of papers focused on specific countries or industries, within those reporting about the policy reported in row. One paper might address more than one country/industry.

Source Author's own elaboration

Table 4 GVC-oriented policies, considering for different upgrading outcomes

\begin{tabular}{|c|c|c|c|c|c|c|c|c|c|c|c|c|}
\hline & \multicolumn{8}{|c|}{ Economic } & \multicolumn{2}{|c|}{ Social } & \multicolumn{2}{|c|}{ Environmental } \\
\hline & Upgr. & Product & Process & Functional & $\begin{array}{l}\text { Supply } \\
\text { chain }\end{array}$ & Channel & $\begin{array}{l}\text { Inter- } \\
\text { chain }\end{array}$ & Downgr. & Upgr. & Downgr. & Upgr. & Downgr. \\
\hline Facilitator & $\bullet \bullet \bullet$ & ০৫ & 000 & ০৫ & ००० & ০০০ & ০• & 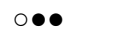 & ००० & ০০০ & & \\
\hline Incentives & $\bullet \bullet \bullet$ & ০• & ০• & ০• & ০০ & ००० & $\circ \diamond \bullet$ & 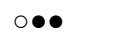 & 000 & 000 & & \\
\hline $\begin{array}{l}\text { Trade } \\
\text { facilitations }\end{array}$ & $\bullet \bullet \bullet$ & ০৫ & ০০০ & & $০ ০ \bullet$ & ০॰ & ০৫ & ০৫ & ০॰ & ০॰ & & 000 \\
\hline Services & $\bullet \bullet \bullet$ & ০৫ & 000 & ০০০ & ০০০ & ০০০ & ০৫ & 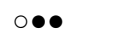 & ০॰ & ০০০ & 000 & \\
\hline $\begin{array}{l}\text { Knowledge } \\
\text { infrastructure }\end{array}$ & $\bullet \bullet \bullet$ & ০• & ০• & $০ \diamond \bullet$ & ০০০ & ০০ & $০ \diamond \bullet$ & $\circ \bullet \bullet$ & & & & \\
\hline $\begin{array}{l}\text { Infrastructure } \\
\text { building }\end{array}$ & $\bullet \bullet \bullet$ & 000 & ০০০ & ০৫ & ০৫ & 000 & ০॰ & ০॰ & ০০০ & 000 & & \\
\hline Regulator & $\bullet \bullet \bullet$ & ০• & ০০০ & & & ০০০ & ০০০ & 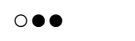 & ০৫ & ০০০ & & \\
\hline $\begin{array}{l}\text { Regulatory } \\
\text { framework }\end{array}$ & $\bullet \bullet \bullet$ & ০৫ & ০০০ & & & & ০০ & $\circ \bullet \bullet$ & ০• & ০৫ & 000 & ০০০ \\
\hline $\begin{array}{l}\text { Protective } \\
\text { measures }\end{array}$ & $\bullet \bullet \bullet$ & 000 & & & & ০॰ & 000 & $\bullet \bullet \bullet$ & & 000 & & 000 \\
\hline Producer & $\bullet \bullet \bullet$ & $\diamond \bullet \bullet$ & ০०० & ০৫ & & & ००० & 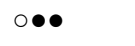 & ००० & & ००० & \\
\hline Buyer & $\bullet \bullet \bullet$ & $\bullet \bullet \bullet$ & 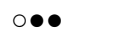 & ০৫ & & 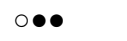 & ০• & & 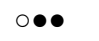 & & ০• & \\
\hline
\end{tabular}

Note $\bullet \bullet \bullet=$ major occurrence,$\circ \bullet=$ significant occurrence, $\circ \circ \bullet=$ moderate occurrence, $\circ \circ \circ=$ minor occurrence, empty $=$ marginal occurrence . Occurrence is calculated considering the incidence of records reporting on that upgrading outcome, within those reporting about the policy reported in row. As for the sub-categories of economic upgrading, occurrence is calculated considering the incidence on records reporting economic upgrading in the context of the policy reported in row; not in all cases it was possible to disentangle across sub-categories of upgrading.

Source Author's own elaboration.

(Rossi, 2015). The vast majority of such agreements cover traditional manufacturing sectors; they are developed mostly by national governments in lower/upper-middle income economies. 
Another highly diffused instrument adopted by national policymakers is to provide incentives, subsidies or favorable taxes. Grants targeting local producers are often aimed at securing increased local value capture, raising local technological capabilities (e.g., upgrading the production techniques of coffee farmers in Rwanda - see Behuria, 2019); supporting the development of new industries (such as in the case of high-speed rails in China - see Băzăvan, 2019); or even facilitating geographical delocalization (as in the case of the Chongquing region in China, where logistics subsidies were offered to local and foreign firms, to aid the creation of a supply base in the area - see Gao et al., 2019). Incentives targeting foreign firms are primarily oriented towards enhancing GVC participation, by attracting FDI. Tax incentives or allowances are often aimed at attracting global lead firms to relocate production or research and development facilities in-country (e.g., Markiewicz, 2019; Yang, 2014), to support the development of local knowledge endowments. Such initiatives have been developed by countries as diverse as China, Colombia, and Costa Rica, with the aim of attracting and retaining FDI in high-technology sectors, and to encourage global lead firms to establish R\&D activities in-country (Gao et al., 2019; Kergroach, 2019). Several cases also report specific incentives to support the opening of higher value-added markets (e.g., Alam \& Natsuda, 2016; Moazzem \& Sehrin, 2016). Interestingly, we also observed examples of leveraging tax liabilities and incentives to support better social conditions (e.g., Behuria, 2019; Pedersen et al., 2019). Incentives are particularly apparent in the context of complex products, and in upper-middle countries.

National policy-makers also initiate policies to strengthen infrastructure capacity, an initiative that encompasses all four GVC-oriented policy aims considered (Pietrobelli \& Staritz, 2018). Such initiatives can involve improvements to logistical infrastructure (e.g., roads, airport, ports, etc.) spanning national borders (e.g., Dannenberg et al., 2018; Gao et al., 2019); telecommunication infrastructure (Riain, 2004; Yeung, 2019); and productive infrastructure involving the creation of industrial parks and warehouses, to help develop specific industries (e.g., Felker, 2009; Gao et al., 2019; Ngo, 2017). The case of the SAGCOT corridor in Tanzania is particularly interesting, as such investment clearly reflects a value-chain approach aimed at connecting actors working at different scales of the GVC (see Dannenberg et al., 2018). Several examples in this respect are found across both lower- and upper-middle economies, especially in the context of complex products.

In relation to complex products, and particularly in the context of upper-middle economies, national policy-makers invest to support their country's knowledge infrastructure. Such investments are often aimed at enhancing local skill development, value capture, and promoting broader GVC participation. Such policies involve the development of vocational projects, providing hands-on training to workers and potential entrepreneurs (e. g., Athukorala, 2017; Kergroach, 2019; Tessmann, 2020), or creating stronger links with education institutions, including universities and specialized research centers (e.g., Gao et al., 2019; Rasiah et al., 2016).

Services to support local firms are found to be particularly helpful in targeting value capture (Kleibert, 2015; Wentink et al., 2017). These policies can range from the provision of technical advice and services to support product exports, to the establishment of specific instruments - such as in the case of the Rwandan farmers, wherein local government established a coffee washing station to support product and process upgrading - explicitly aimed at integrating suppliers into GVCs (see Kergroach, 2019). Another interesting case in this regard is the South African fishery industry: cooperatives were formed to provide an array of services to upgrade local firm capabilities, reinforce backward and forward linkages, and support increased value capture by strengthening suppliers' collective bargaining power (see Wentink et al., 2017). Advisory services also support the achievement of social goals, as reported by Rossi (2015) and Tewari (2017) in the cases of textile and apparel GVCs, where factory-level meetings and self-help groups were used to provide basic knowledge and skills to workers. As reflected in Table 3, the array of services described here oriented towards GVC facilitation encompass a variety of industrial and geographical contexts.

In the majority of cases analyzed wherein the state has played a facilitating role, a variety of economic upgrading outcomes have been identified, particularly regarding product or inter-chain upgrading (see Table 4). This is especially apparent in relation to strengthening links between research institutions and local companies (knowledge infrastructure), to enable local firms to enter new industries and adopt more value-added activities (e.g., Băzăvan, 2019; Butollo \& Ten Brink, 2018). A case 
in point is the Penang Export Hub, where a stateprogram was launched specifically to support firm innovation, access to markets and advanced technologies in the electronics sector to boost local R\&D capabilities (see Athukorala, 2014; Athukorala, 2017). Similar upgrading trajectories are observed when incentives are introduced. Interestingly, GVC facilitation (particularly via the introduction of services, see Table 4), is also associated with enhanced social conditions, principally in the form of improved measurable standards as opposed to enabling rights (e.g., Azmeh, 2014a, b; Rossi, 2015). For example, in Mewat (India) increased child education rate, higher incomes, and better working conditions were achieved via the formation of self-help groups (SHGs), through which local residents - especially women - were taught basic economic skills and on-the-job training (see Tewari, 2017). In several of the instances analyzed, and particularly in the case of incentives, downgrading dynamics were also observed.

\section{State as Regulator}

A number of cases demonstrate how national policymakers can influence value capture (and, to a lesser extent GVC participation), via its regulatory role - imposing restriction on foreign or local firms (see Table 2). To put these observations into wider context, and as reflected in our review of the gray policy literature, recent shifts in trade policy following a notable backlash against economic globalization (Horner \& Alford, 2019) reaffirm the increased significance of the state's regulatory role. The ILO's (2015) 'Value Chain Development for Decent Work' policy report seeks to move beyond pro-poor growth and urge policymakers to consider the effects of interventions on working conditions, such as through effective state regulation and supportive enforcement mechanisms. UNCTAD's (2017) 'World Investment Report' also highlights a notable shift towards investment restrictions and regulations concerning foreign takeovers, relative to those in place in the 1990s.

Indeed, the state is often engaged in designing and implementing regulation that affect product price and quality (e.g., Gao et al., 2019; Tessmann, 2020), labor and environmental standards (e.g., Alford, 2016; Hossain, 2019; Yoshida, 2017). Such regulations are primarily aimed at supporting value capture and alternative value appropriation structures in GVCs. For example, having understood the power imbalance in the TV format GVC, the UK government implemented terms of trade between broadcasters and producers, creating an IP regime to support localized value appropriation and development of the TV broadcasting industry (Chalaby, 2017). Other cases describe such goals being achieved by removing certain intermediary agents in the chain (e.g., Tewari, 2017; Wentink et al., 2017). Our analysis indicates that such regulatory interventions occur primarily in natural resourcebased and traditional manufacturing industries, and in the context of upper-middle countries (Table 3).

Protective measures against foreign firms - mostly introduced in the context of complex product GVCs and in upper-middle countries (see Table 3) - are often aimed at value capture and upgrading a local supply base until 'domestic companies become strong enough to resist international competition' (Băzăvan, 2019: 4). These policies can take the form of tariffs applied to imports, local content requirements, or restrictions on foreign investment. Such policies are significantly impacting the geographies of GVCs/GPNs and relationships within and among firms, both at a local and international level (e.g., Azmeh, 2015; Curran et al., 2019). The Chinese experience of new energy vehicles is interesting in this regard, as such restrictions have prompted global lead firms to 'team up' with local producers, to accelerate transfer of state-of-the-art technologies developed in the USA and Europe (see Yeung, 2019).

The stringency of the regulatory framework is found to be especially effective in supporting product upgrading (see Table 4). The setting of quality or price standards (e.g., Behuria, 2019) and/ or banning specific (low-value) technologies (e.g., Butollo \& Ten Brink, 2018), can foster shifts in local production toward higher value-added products. State regulation has also been associated with improved social conditions, requiring or supporting the adoption of internationally or locally developed certification schemes (Behuria, 2019; Schouten \& Hospes, 2018); and through stricter enforcement of labor regulation (e.g., Braun-Munzinger, 2019; Hossain, 2019). However, downsides have also been documented, with protective regulatory measures often contributing to concurrent downgrading and upgrading outcomes, including environmental degradation. Such mixed outcomes have been attributed to enforcements problems (see Yoshida, 2017), or the unintended consequence of introducing measures that protect certain individual firms as opposed to achieving overall competitiveness. 


\section{State as Producer}

We observed very few instances of states leveraging their role as producer to enact GVC-oriented policies, either in the systematic literature review or concurrent analysis of IO publications, with those observed primarily occurring in the context of complex products (Table 3). State-owned enterprises are often reported in the analysis of Chinese (Defraigne, 2017; Liu \& Yang, 2013; Zhu, 2015) or more generally in East Asian GVCs (e.g., Ngo, 2017), wherein national or sub-national policymakers leveraged the producer role to support the technological development of local industries and innovative capabilities. Such a role is primarily implemented to achieve value-capturing opportunities relative to ensuring GVC participation (Table 2). The case of Rwanda coffee making described by Behuria (2019) provides an interesting explanation of why GVC-oriented policies differ from traditional Private Sector Development policies. To support the move toward higher-value coffee, the Rwandan state invested in coffee roasting, processing factories and retail outlets. The development of the whole chain locally, initially supported by sub-national government investments, sustained the effective diversification of final markets, as well as the process and functional upgrading of local firms.

A vast majority of the papers on the state's role as producer suggest it is linked to product upgrading (see Table 4). For example, in the Chinese liquid crystal display industry, municipal governments heavily invested in local companies to support indigenous innovation and the development of higher-value-added products (Yang, 2014). Similar outcomes have been reported in a different empirical context, such as coffee production in Africa described above (Behuria, 2019). However, a number of papers also highlighted that such a role can be counterproductive if not implemented effectively, in some cases resulting in economic downgrading. This is due to the fact that while stateowned companies can be locally competitive and benefit from special local market conditions, they do not necessarily develop the skills needed to enter more competitive, foreign markets (see e.g., Chen \& Xue, 2010).

\section{State as Buyer}

Our review also found that few studies examined the state's role as buyer in relation to GVC-oriented policies, perhaps due to the fact that public sector procurement is a new and emerging focus of GVCs/
GPNs research (Hughes et al., 2019). The few examples observed were primarily in the context of complex product GVCs located in upper-middle or high-income economies (Table 3). This state role is often established to support the development of new industries, as in the case of the LED lighting products or electric vehicles in China (see Butollo \& Ten Brink, 2018; Yeung, 2019), or the furniture sector in Mexico (see Klooster \& Mercado-Celis, 2016). Furthermore, in a significant number of cases analyzed, the state's buyer role was aimed at achieving improved environmental performance at a local level (Table 2). Such evidence is in line with the increased emphasis on (social and environmental) responsibility that governments, especially in developed countries, are placing on their purchasing activities (see Hughes et al., 2019).

In relation to upgrading, the few papers addressing the state's role as buyer report that such action has been beneficial for economic, and particularly product, upgrading. Particularly when local producers have not yet achieved the standards required to serve foreign markets in new, value-added products, public procurement can play a pivotal role in strengthening their competitiveness (e.g., Chalaby, 2017; Gao et al., 2019). More specifically, public procurement can accelerate domestic firms' ability to achieve economies of scale and develop advanced production technologies, while enabling own-brand development, initially for local and then subsequently foreign markets (see e.g., Butollo $\&$ Ten Brink, 2018). As evidenced in Table 4, the state's buyer role can also be particularly effective in strengthening social and environmental standards, requiring the adoption of Ethical Sourcing Policies - as in the case of Transport of London described in Martin-Ortega and O'Brien (2017); or by ensuring sustainable inputs (certified wood) are used in manufactured products, such as the case of school furniture production in the Oaxaca region (see Klooster \& Mercado-Celis, 2016).

\section{CO-EXISTENCE OF UPGRADING AND DOWNGRADING: TENSIONS AND TRADE-OFFS}

As summarized in Table 4, a large number of contributions analyzed observe some form of economic upgrading. Other than a general increase in employment and number of local firms ${ }^{10}$, product and process are the types most commonly reported, with social and environmental upgrading relatively less documented. Furthermore, while numerous cases indicate that state policies can enable local 
economies to leverage increased gains from GVC participation, often mixed results emerge, involving either cases of degraded local conditions, or a failure of policies to achieve their full growth potential. This is particularly evident in cases where the state acts as producer and regulator (and especially when implementing protective measures). Several reasons motivate the co-existence of economic up and downgrading dynamics. In the case of trade facilitation or protective regulatory measures, economic upgrading outcomes are found to be heterogeneous across firms: some firms are favored by policy initiatives, whereas others (often the smallest ones or those located in rural areas) are left behind (Martinez-Covarrubias et al., 2017; Yoshida, 2017 ${ }^{11}$. A similar dynamic is observed in relation to social upgrading, where heterogeneities at the worker level also emerge (Plank \& Staritz, 2016). Numerous contributions also report that some forms of economic upgrading have been achieved (e.g., increased export shares and local firm access to GVCs), but others (e.g., higher local value content) have not (e.g., Azmeh, 2015; Pavlínek, 2016). Furthermore, downgrading might temporally follow upgrading, as positive, shortterm policy outcomes are not necessarily maintained over time (e.g., Azmeh, 2014a, b; Pedersen et al., 2019).

Interestingly, the three types of upgrading are also found to trade-off one another, as predicted by Barrientos et al. (2011a, b), and De Marchi et al. (2019). For example, social and economic up and downgrading are often found to coexist (e.g., Braun-Munzinger, 2019; Dannenberg et al., 2018; Plank \& Staritz, 2016), with observable tensions between economic and environmental upgrading another clear case in point (e.g., Azmeh, 2014a, b, 2015; Braun-Munzinger, 2019; Dannenberg et al., 2018). To briefly recount two pertinent examples, in the textile GVC in China, pollution reduction achieved through stringent state policy has led to the closure of several local companies unable to meet new environmental standard requirements (see Braun-Munzinger, 2019). In contrast, increasing industrialization driven by the development of a growth corridor in Tanzania, has been coupled with a degradation of soil conditions due to deforestation, a reduction in biodiversity and precarization of employment (see Dannenberg et al., 2018).

\section{THE MEDIATING ROLE OF POLICY DESIGN AND IMPLEMENTATION}

The analysis provided above indicates which state roles are more likely to achieve economic, social, and environmental upgrading or downgrading. However, it also disclosed heterogeneities in the results - some policymakers have been more effective than others. It is clear that designing and implementing GVC policies is challenging; ineffective design or implementation of a given policy might prevent states from reaping the full benefits of original policy aims or result inadvertently in downgrading outcomes. By comparing the cases of failures and successes and drawing from the theoretical literature, we identify six aspects specifically relating to GVC-oriented policies that policymakers should consider to effectively achieve economic, social, or environmental upgrading - that cut across the four state roles (see also Kaplinsky, 2014; Kaplinsky \& Morris, 2016).

Regarding the design phase, GVC policies should stem from an accurate understanding of a given GVC's functioning and address all the relevant actors in the chain; including specific segments of the chain (e. g., input producers), firms populating the segments, and even typologies of workers. Segments of the chain not considered in policies could become bottlenecks (see for example the case of Rwanda coffee GVC detailed in Behuria, 2019). Limits to upgrading could also arise in the event there are not enough local firms specialized in, or having the resources to take advantage of policies introduced (see e.g., Yeung, 2019). Finally, (social) upgrading policies could be inefficient if they are addressing only certain workers' employment conditions (i.e., regular workers and not precarious workers, see Alford, 2016 and ILO, 2015). In line with Morris and Staritz (2019), this discussion points to the importance of equipping governmental officials with the skills to map GVCs, assess their power imbalances and governance structures, and identify upgrading opportunities. Recently published academic articles (Whitfield \& Staritz, 2020; Whitfield et al., 2020) and IO policy reports (UNCTAD 2020; World Bank, 2020) further reaffirm the importance of nation-states developing industrial and sectoral policies that account for the specificities of cross-border GVC linkages and the ongoing significance of global lead firms. This requires that national policymakers adopt a GVC mapping methodology detailed in Fernandez-Stark 
and Gereffi (2019) and Frederick (2019), which has been widely adopted by IOs despite not always being correctly applied (Gereffi, 2019; Mayer \& Gereffi, 2019).

Furthermore, a key challenge in the design of GVC-oriented policies lies in the need to acknowledge, mediate, and prioritize among different interests, which are dependent on the particular characteristics of $a G V C$, accounting for the degree of GVC integration, level of economic development, and specific industry dynamics. It is important for national policymakers to be aware that, even within the same countries, actors at different nodes of the GVC can have diverse interests, for example regarding trade facilitation interventions. The other side of this coin is the fact that GVC-oriented policies will impact firms differently, depending on their position and integration in GVCs (e.g., Butollo \& Ten Brink, 2018; Dannenberg et al., 2018; Kergroach, 2019; Moazzem \& Sehrin, 2016).

Other important and (potentially) conflicting interests to be acknowledged are those among global lead firms and national policymakers (Abdulsamad \& Manson, 2019; Pavlínek, 2016; Pietrobelli \& Staritz, 2018), which might prevent policy effectiveness. In the Ivorian Cashew Industry, the resistance of lead firms to pay a premium price for quality products supported by local government initiatives prevented local farmers from capturing more value added, despite strong policy efforts put in place (Tessmann, 2020). Similar resistance can be found in the implementation of (labor) standards (Alford, 2016; Schouten \& Hospes, 2018). A key challenge, therefore, is that global lead firm strategies fall outside the scope of national policies and jurisdictions. However, analysis based on this review indicates that policymakers can leverage various strategies in order to implement effective strategies in the context of such geographical constraints (see e.g., Chalaby, 2017).

One of the key elements to ensure the effective design of GVC-oriented policies is the involvement of multiple actors in the design (and implementation) of GVC-oriented policies. Policies in a GVC order demand an 'understanding of trans-scalar interactions' across private, private and civil society actors, and regimes (Alford, 2016: 56; Paus et al., 2008). Most of the cases in which policies have successfully achieved improved social standards have involved IOs, states, NGOs, firms' association, and even (lead) firms (e.g., Hossain, 2019; Rossi, 2015; Tewari, 2017; see also ILO, 2015). Almost all of the cases considered involving combinations of public, private, and civil society stakeholders have contributed to positive economic upgrading outcomes (e.g., Behuria, 2019; Pedersen et al., 2019). Similarly, evidence indicates that the combined and coordinated engagement of different institutional actors within the state at national level (e.g., both the Ministries of Agriculture and of Industry, as in Tessmann, 2020; or both ministries of Woman and Child Development and of Rural Development, as in Tewari, 2017) or across geographical jurisdictions (e.g., central, provincial, municipality authorities, as in Dong \& He, 2018; Gao et al., 2019), can result in effective GVC-oriented policy outcomes.

Lessons from failing cases suggest that the implementation stage is decisive: policymakers should ensure the required resources and capabilities are available at the local level - for example, by providing tailored support to help domestic firms enhance value capture through GVC participation (Paus \& Gallagher, 2008; Rutherford \& Holmes, 2007; Wentink et al., 2017), or understanding the specific (labor) standards required by global lead firms (see Smith et al., 2018; IILS, 2006; ILO, 2015). Particularly when local authorities are involved, national governments should provide sufficient (economic) resources to implement intended policies and support firms operating across all value chain segments (e.g., Gao et al., 2019; Schouten \& Hospes, 2018). Specific capabilities and knowledge required to capture increased benefits through GVC participation also need to be appropriately coordinated, targeted, and monitored to ensure they reach their intended recipients (e.g., Ngo, 2017; Schouten \& Hospes, 2018). For example, in the context of the Mexican complex products GVCs analyzed by Durán (2019), governments heavily invested in universities to support local skill development and improve the R\&D efforts of OEMs, yet with limited success due to weak links between firms and universities, along with the inability of local agencies to effectively transfer academic expertise to enterprises. This lesson highlights that implementation of GVC-oriented policies requires a deeper understanding of the particular resource constraints and needs of production contexts connected to GVCs, accounting for macro, meso, and micro levels of analysis, which requires state policymakers to broaden their expertise.

Finally, it is worth mentioning that to effectively mediate participation in GVCs and/or capture more of the value produced therein, requires a mix of state policies alongside domestic firm efforts. In almost all the cases reviewed, more than one policy initiative 
has been simultaneously introduced (e.g., Kergroach, 2019; Pietrobelli \& Puppato, 2016), with the mix often changing over time (e.g., Hsu, 2011; Rutherford \& Holmes, 2007). While analyzing what is the best sequence or combination of policies to support upgrading and GVC participation falls outside the scope of this article, it is important to highlight that such complex and systemic outcomes cannot be achieved through one policy intervention alone. Synergies could arise across policies (for example among industrial and labor policies, as described in Braun-Munzinger, 2019); and the implementation of one policy might later require the introduction of another (for example, the strengthening of the local supply base driven by the provision of incentives requires investments to strengthen knowledge infrastructure - see e.g., Pavlinek, 2016). While the scope of this article is on the role of national policymakers, it is important to stress that state policies are not the sole contributors to up or downgrading outcomes: firms' capability endowment and their entrepreneurial effort are essential in supporting effective participation or upgrading in GVCs. In line with Morrison et al., (2008) and Giuliani, de Marchi, \& Rabellotti (2017), the cases reviewed in this article suggest that larger and more capable firms are better equipped to exploit opportunities deployed by GVC-oriented policies, to improve their position in the chain, highlighting that the impact of policies might be uneven across firms (Behuria, 2019; Dannenberg et al., 2018; Pedersen et al., 2019; Plank \& Staritz, 2016; Yoshida, 2017).

\section{CONCLUSION}

An increasing body of research indicates that state policies are crucial in the context of GVCs. This is reflected both in more robust theorization of the different roles states play in recent academic literature (Alford \& Phillips, 2018; Horner, 2017; Horner \& Alford, 2019; Mayer \& Phillips, 2017; Smith, 2015), alongside an increasing appreciation among IOs of a need for state policies tailored to the specificities of coordinated production that distinguish GVCs from other forms of industrial organization (ILO, 2015; Mayer \& Gereffi, 2019; UNCTAD, 2020; UNIDO, 2015; World Bank, 2020; WTO, IDE-JETRO, OECD, VIBE, \& World Bank, 2019). In some respects, this reflects a move away from traditional liberal vs interventionist 'one-sizefits-all' debates regarding the role states can and should play, towards a more targeted appreciation of the particular global-local linkages that exist between lead firms, suppliers and a host of other stakeholders linked to GVCs. Our 'cut' into these debates has been to operationalize and systematically explore the extent to which policies falling under four defined roles of the state - facilitator, regulator, producer, and buyer - are connected to enhanced GVC participation, value capture, economic, social, and environmental up or downgrading.

For this purpose, we implemented a systematic review of the academic literature on policy-oriented GVCs, which have been coded and subject to quantitative analysis, to provide a broad overview of the issues at stake. While such an approach is not free of limitations, it has enabled us to make an important contribution on the complex relationship between state roles, policy effectiveness, and up/downgrading in GVCs. The analysis suggests that when enhancing GVC participation is the goal, policymakers often adopt facilitative strategies to invest in the development of (knowledge) infrastructures or in the provision of incentives. With regards to ensuring local firms are better able to retain a higher share of the value produced, facilitative measures such as enhancing access to services and knowledge infrastructure gain more relevance. When social or environmental goals are the target, regulatory measures and provision of services are preferred, with trade agreements often leveraged to achieve social objectives. Our analysis also highlights which initiatives are more likely to be associated to specific types of upgrading trajectories, with economic (and particularly product and process) being the type most commonly reported, and social and environmental relatively less documented. While our analysis suggests that state policies can enable local economies to leverage increased gains from GVC participation, we observed numerous examples of mixed results (particularly in relation to the state's producer and regulator roles), including either degraded local conditions or a failure to achieve intended policy outcomes. In the case of trade facilitation or protective regulatory measures, economic upgrading outcomes were found to favor some firms, with others left behind. We also observed trade-offs across the three types of upgrading under review; social and economic up and downgrading were often found to coexist, with observable tensions between economic and environmental upgrading also documented. Finally, we discussed the challenges related to the design and implementation of 
Table A.1 The contributions considered in the systematic literature review

\begin{tabular}{|c|c|c|c|c|c|c|c|c|}
\hline \multirow[t]{2}{*}{ Code } & \multirow[t]{2}{*}{ Authors } & \multirow[t]{2}{*}{ Year } & \multirow[t]{2}{*}{ Title } & \multirow{2}{*}{$\begin{array}{l}\text { Countries } \\
\text { analyzed }\end{array}$} & \multirow{2}{*}{$\begin{array}{l}\text { Sectors } \\
\text { analyzed }\end{array}$} & \multicolumn{3}{|c|}{ Up/Down-grading } \\
\hline & & & & & & Economic & Environmental & Social \\
\hline 1 & Tessmann & 2019 & $\begin{array}{l}\text { Global value chains and policy practice: } \\
\text { The making of linkages in the Ivorian } \\
\text { cashew industry }\end{array}$ & LM & NRB & $\uparrow \square$ & & \\
\hline 13 & Behuria & 2019 & $\begin{array}{l}\text { The domestic political economy of } \\
\text { upgrading in global value chains: how } \\
\text { politics shapes pathways for upgrading } \\
\text { in Rwanda's coffee sector }\end{array}$ & $\mathrm{LI}$ & NRB & $\uparrow$ & $\uparrow$ & $\uparrow$ \\
\hline 25 & Kergroach & 2019 & $\begin{array}{l}\text { National innovation policies for } \\
\text { technology upgrading through GVCs: } \\
\text { A cross-country comparison }\end{array}$ & UM; HI & & $\uparrow$ & & \\
\hline 42 & Durán & 2019 & $\begin{array}{l}\text { Globalization and the scrambling } \\
\text { process of catching up in Mexico }\end{array}$ & UM & & $\uparrow$ & & $\uparrow$ \\
\hline 47 & Aberg, Becker & 2019 & $\begin{array}{l}\text { The world is more than a stage: foreign } \\
\text { policy, development, and spatial } \\
\text { performativity in Ethiopia }\end{array}$ & $\mathrm{LI}$ & & $\uparrow$ & & \\
\hline 48 & $\begin{array}{l}\text { Braun- } \\
\text { Munzinger }\end{array}$ & 2019 & $\begin{array}{l}\text { Chinese CSR standards and industrial } \\
\text { policy in GPNs }\end{array}$ & UM & TM & $\square$ & $\uparrow$ & $\uparrow$ \\
\hline 49 & Gao et al. & 2019 & $\begin{array}{l}\text { Governance capacity, state policy and } \\
\text { the rise of the Chongqing notebook } \\
\text { computer cluster }\end{array}$ & UM & $C P$ & $\uparrow$ & & \\
\hline 59 & Mayer, Phillips & 2019 & $\begin{array}{l}\text { Global inequality and the Trump } \\
\text { administration }\end{array}$ & UM & $\begin{array}{l}\text { NRB; } \\
\text { CP; TM }\end{array}$ & $\square$ & $\square$ & $\square$ \\
\hline 60 & Markiewicz & 2019 & $\begin{array}{l}\text { Stuck in second gear? EU integration } \\
\text { and the evolution of Poland's } \\
\text { automotive industry }\end{array}$ & $\mathrm{HI}$ & $\mathrm{CP}$ & $\uparrow$ & & \\
\hline 69 & Băzăvan & 2019 & $\begin{array}{l}\text { Chinese government's shifting role in } \\
\text { the national innovation system }\end{array}$ & UM & $S ; C P$ & $\uparrow \square$ & & \\
\hline 75 & Pedersen et al. & 2019 & $\begin{array}{l}\text { Mining-sector dynamics in an era of } \\
\text { resurgent resource nationalism: } \\
\text { Changing relations between large-scale } \\
\text { mining and artisanal and small-scale } \\
\text { mining in Tanzania }\end{array}$ & $\mathrm{LI}$ & & $\uparrow \square$ & & \\
\hline 79 & Hossain & 2019 & $\begin{array}{l}\text { Rana Plaza, disaster politics, and the } \\
\text { empowerment of women garment } \\
\text { workers in Bangladesh }\end{array}$ & LM & TM & & & $\uparrow \square$ \\
\hline 103 & Heron et al. & 2018 & $\begin{array}{l}\text { Global Value Chains and the } \\
\text { Governance of 'Embedded' Food } \\
\text { Commodities: The Case of Soy }\end{array}$ & & NRB & & $\uparrow$ & \\
\hline 105 & $\begin{array}{l}\text { Dannenberg } \\
\text { et al. }\end{array}$ & 2018 & $\begin{array}{l}\text { Spaces for integration or a divide? } \\
\text { New-generation growth corridors and } \\
\text { their integration in global value chains } \\
\text { in the Global South }\end{array}$ & $\begin{array}{l}\text { LI; LM; } \\
\text { UM }\end{array}$ & NRB & $\uparrow$ & $\square$ & $\square$ \\
\hline 111 & $\begin{array}{l}\text { Abramova, } \\
\text { Garanina }\end{array}$ & 2018 & $\begin{array}{l}\text { Russian MNEs Under Sanctions: } \\
\text { Challenges for Upgrading in GVCs } \\
\text { (Cases of Energy and IT Industries) }\end{array}$ & UM & $\begin{array}{l}\text { NRB; } \\
\text { CP }\end{array}$ & $\uparrow \square$ & & \\
\hline 113 & $\begin{array}{l}\text { Athukorala, } \\
\text { Ekanayake }\end{array}$ & 2018 & $\begin{array}{l}\text { Repositioning in the global apparel } \\
\text { value chain in the post-MFA era: } \\
\text { Strategic issues and evidence from Sri } \\
\text { Lanka }\end{array}$ & UM & TM & $\uparrow$ & $\uparrow$ & $\uparrow$ \\
\hline 122 & $\begin{array}{l}\text { Butollo, Ten } \\
\text { Brink }\end{array}$ & 2018 & $\begin{array}{l}\text { A great leap? Domestic market growth } \\
\text { and local state support in the } \\
\text { upgrading of China's LED lighting } \\
\text { industry }\end{array}$ & UM & $C P$ & $\uparrow$ & & \\
\hline
\end{tabular}


Table A.1 (Continued)

\begin{tabular}{|c|c|c|c|c|c|c|c|c|}
\hline \multirow[t]{2}{*}{ Code } & \multirow[t]{2}{*}{ Authors } & \multirow[t]{2}{*}{ Year } & \multirow[t]{2}{*}{ Title } & \multirow{2}{*}{$\begin{array}{l}\text { Countries } \\
\text { analyzed }\end{array}$} & \multirow{2}{*}{$\begin{array}{l}\text { Sectors } \\
\text { analyzed }\end{array}$} & \multicolumn{3}{|c|}{ Up/Down-grading } \\
\hline & & & & & & Economic & Environmental & Social \\
\hline 123 & $\begin{array}{l}\text { Thoburn, } \\
\text { Natsuda }\end{array}$ & 2018 & $\begin{array}{l}\text { How to conduct effective industrial } \\
\text { policy: a comparison of automotive } \\
\text { development in the Philippines and } \\
\text { Indonesia }\end{array}$ & LM & $\mathrm{CP}$ & $\square$ & & \\
\hline 145 & $\begin{array}{l}\text { Schouten, } \\
\text { Hospes }\end{array}$ & 2018 & $\begin{array}{l}\text { Public and private governance in } \\
\text { interaction: Changing interpretations } \\
\text { of sovereignty in the field of Sustainable } \\
\text { Palm Oil }\end{array}$ & LM & NRB & & $\uparrow$ & \\
\hline 158 & Dong, $\mathrm{He}$ & 2018 & $\begin{array}{l}\text { Linking the past to the future: A reality } \\
\text { check on cross-border timber trade } \\
\text { from Myanmar (Burma) to China }\end{array}$ & LM & NRB & $\square$ & $\square$ & \\
\hline 162 & Chalaby & 2017 & $\begin{array}{l}\text { Can a GVC-oriented policy mitigate the } \\
\text { inequalities of the world media system? } \\
\text { Strategies for economic upgrading in } \\
\text { the TV format global value chain }\end{array}$ & $\mathrm{HI}$ & $S$ & $\uparrow$ & & \\
\hline 163 & Yoshida & 2017 & $\begin{array}{l}\text { Local institutions and global value } \\
\text { chains: Development and challenges of } \\
\text { shrimp aquaculture export industry in } \\
\text { Vietnam }\end{array}$ & LM & NRB & $\uparrow \square$ & & \\
\hline 178 & Araújo, Flaig & 2017 & $\begin{array}{l}\text { Trade restrictions in Brazil: Who pays } \\
\text { the price? }\end{array}$ & UM & & $\square$ & & \\
\hline 179 & Chiarini et al. & 2017 & $\begin{array}{l}\text { Access to knowledge and catch-up: } \\
\text { Exploring some intellectual property } \\
\text { rights data from Brazil and South Korea }\end{array}$ & $\mathrm{HI}$ & & $\uparrow$ & & \\
\hline 190 & Tewari & 2017 & $\begin{array}{l}\text { Relational Contracting at the Bottom of } \\
\text { Global Garment Value Chains: Lessons } \\
\text { from Mewat }\end{array}$ & LM & TM & & & $\uparrow$ \\
\hline 196 & Nahm & 2017 & $\begin{array}{l}\text { Renewable futures and industrial } \\
\text { legacies: Wind and solar sectors in } \\
\text { China, Germany, and the United States }\end{array}$ & UM; HI & $\mathrm{CP}$ & $\uparrow$ & & \\
\hline 199 & Ngo & 2017 & $\begin{array}{l}\text { Industrial Development, Liberalisation } \\
\text { and Impacts of Vietnam-China Border } \\
\text { Trade }\end{array}$ & LM & TM & $\square$ & & \\
\hline 203 & Wentink et al. & 2017 & $\begin{array}{l}\text { Co-governance and upgrading in the } \\
\text { South African small-scale fisheries value } \\
\text { chain }\end{array}$ & UM & NRB & $\uparrow \square$ & & \\
\hline 223 & $\begin{array}{l}\text { Martin-Ortega, } \\
\text { O'Brien }\end{array}$ & 2017 & $\begin{array}{l}\text { Advancing respect for labour rights } \\
\text { globally through public procurement }\end{array}$ & UM; HI & & & & $\uparrow$ \\
\hline 243 & $\begin{array}{l}\text { Pietrobelli, } \\
\text { Puppato }\end{array}$ & 2016 & $\begin{array}{l}\text { Technology foresight and industrial } \\
\text { strategy }\end{array}$ & UM; HI & $\mathrm{CP}$ & $\uparrow$ & & \\
\hline 254 & Rasiah et al. & 2016 & $\begin{array}{l}\text { Epilogue: implications for promoting } \\
\text { firm-level technological capabilities }\end{array}$ & LM; UM & $\mathrm{CP}$ & $\uparrow \square$ & & \\
\hline 256 & Alam, Natsuda & 2016 & $\begin{array}{l}\text { The competitive factors of the } \\
\text { Bangladeshi garment industry in the } \\
\text { post-MFA era }\end{array}$ & LM & TM & $\uparrow \square$ & & \\
\hline 258 & $\begin{array}{l}\text { Moazzem, } \\
\text { Sehrin }\end{array}$ & 2016 & $\begin{array}{l}\text { Economic Upgrading in Bangladesh's } \\
\text { Apparel Value Chain during the Post- } \\
\text { MFA Period: An Exploratory Analysis }\end{array}$ & LM & TM & $\uparrow$ & & $\uparrow \square$ \\
\hline 266 & Pavlínek & 2016 & $\begin{array}{l}\text { Whose success? The state-foreign } \\
\text { capital nexus and the development of } \\
\text { the automotive industry in Slovakia }\end{array}$ & $\mathrm{HI}$ & $C P$ & $\uparrow \square$ & & \\
\hline
\end{tabular}


Table A.1 (Continued)

\begin{tabular}{|c|c|c|c|c|c|c|c|c|}
\hline \multirow[t]{2}{*}{ Code } & \multirow[t]{2}{*}{ Authors } & \multirow[t]{2}{*}{ Year } & \multirow[t]{2}{*}{ Title } & \multirow{2}{*}{$\begin{array}{l}\text { Countries } \\
\text { analyzed }\end{array}$} & \multirow{2}{*}{$\begin{array}{l}\text { Sectors } \\
\text { analyzed }\end{array}$} & \multicolumn{3}{|c|}{ Up/Down-grading } \\
\hline & & & & & & Economic & Environmental & Social \\
\hline 271 & Azmeh & 2015 & $\begin{array}{l}\text { Transient global value chains and } \\
\text { preferential trade agreements: Rules of } \\
\text { origin in US trade agreements with } \\
\text { Jordan and Egypt }\end{array}$ & LM; UM & TM & $\uparrow \square$ & $\square$ & \\
\hline 301 & Rossi & 2015 & $\begin{array}{l}\text { Better work: Harnessing incentives and } \\
\text { influencing policy to strengthen labour } \\
\text { standards compliance in global } \\
\text { production networks }\end{array}$ & LI; LM & TM & $\uparrow$ & & $\uparrow$ \\
\hline 307 & $\begin{array}{l}\text { Athukorala, } \\
\text { Veeramani }\end{array}$ & 2019 & $\begin{array}{l}\text { From import substitution to integration } \\
\text { into global production networks: The } \\
\text { case of the Indian automobile industry }\end{array}$ & LM & $\mathrm{CP}$ & $\uparrow$ & & \\
\hline 308 & Ofreneo & 2016 & $\begin{array}{l}\text { Auto and car parts production: can the } \\
\text { Philippines catch up with Asia? }\end{array}$ & LM & $\mathrm{CP}$ & $\square$ & & \\
\hline 313 & Yeung & 2019 & $\begin{array}{l}\text { 'Made in China 2025': the } \\
\text { development of a new energy vehicle } \\
\text { industry in China }\end{array}$ & UM & $C P$ & $\uparrow \square$ & & \\
\hline 314 & Athukorala & 2017 & $\begin{array}{l}\text { Global productions sharing and local } \\
\text { entrepreneurship in developing } \\
\text { countries: Evidence from Penang } \\
\text { export hub, Malaysia }\end{array}$ & UM & & $\uparrow$ & & \\
\hline 315 & $\begin{array}{l}\text { Klooster, } \\
\text { Mercado-Celis }\end{array}$ & 2016 & $\begin{array}{l}\text { Sustainable Production Networks: } \\
\text { Capturing Value for Labour and Nature } \\
\text { in a Furniture Production Network in } \\
\text { Oaxaca, Mexico }\end{array}$ & UM & $\begin{array}{l}\text { NRB; } \\
\text { TM }\end{array}$ & $\uparrow$ & $\uparrow$ & $\uparrow$ \\
\hline 316 & Plank et al. & 2016 & $\begin{array}{l}\text { Social up- and downgrading of apparel } \\
\text { workers in Romania: fast fashion, post- } \\
\text { socialist transformation, } \\
\text { Europeanization, and the global } \\
\text { economic crisis }\end{array}$ & $\mathrm{HI}$ & TM & $\uparrow$ & & $\uparrow \square$ \\
\hline 317 & Smith et al. & 2018 & $\begin{array}{l}\text { Labor Regimes, Global Production } \\
\text { Networks, and European Union Trade } \\
\text { Policy: Labor Standards and Export } \\
\text { Production in the Moldovan Clothing } \\
\text { Industry }\end{array}$ & LM & TM & & & $\square$ \\
\hline 318 & Alford & 2016 & $\begin{array}{l}\text { Trans-scalar embeddedness and } \\
\text { governance deficits in global } \\
\text { production networks: Crisis in South } \\
\text { African fruit }\end{array}$ & UM & NRB & & & $\square$ \\
\hline 328 & $\begin{array}{l}\text { Intarakumnerd } \\
\text { et al. }\end{array}$ & 2016 & $\begin{array}{l}\text { Global production networks and host- } \\
\text { site industrial upgrading: the case of } \\
\text { the semiconductor industry in Thailand }\end{array}$ & UM & TM & $\uparrow \square$ & & \\
\hline 330 & Plank, Staritz & 2015 & $\begin{array}{l}\text { Global competition, institutional } \\
\text { context and regional production } \\
\text { networks: Up- and downgrading } \\
\text { experiences in Romania's apparel } \\
\text { industry }\end{array}$ & UM & TM & $\uparrow \square$ & & $\square$ \\
\hline 501 & Azmeh & 2014 & $\begin{array}{l}\text { Trade regimes and global production } \\
\text { networks. The case of the Qualifying } \\
\text { Industrial Zones (QIZs) in Egypt and } \\
\text { Jordan }\end{array}$ & $\mathrm{HI}, \mathrm{UM}, \mathrm{LI}$ & TM & $\uparrow$ & $\square$ & $\uparrow \square$ \\
\hline 502 & Azmeh & 2014 & $\begin{array}{l}\text { Labour in global production networks: } \\
\text { Workers in the qualifying industrial } \\
\text { zones (QIZs) of Egypt and Jordan }\end{array}$ & $\mathrm{HI}, \mathrm{UM}, \mathrm{LI}$ & TM & $\uparrow$ & & $\uparrow \square$ \\
\hline
\end{tabular}


Table A.1 (Continued)

\begin{tabular}{|c|c|c|c|c|c|c|c|c|}
\hline \multirow[t]{2}{*}{ Code } & \multirow[t]{2}{*}{ Authors } & \multirow[t]{2}{*}{ Year } & \multirow[t]{2}{*}{ Title } & \multirow{2}{*}{$\begin{array}{l}\text { Countries } \\
\text { analyzed }\end{array}$} & \multirow{2}{*}{$\begin{array}{l}\text { Sectors } \\
\text { analyzed }\end{array}$} & \multicolumn{3}{|c|}{ Up/Down-grading } \\
\hline & & & & & & Economic & Environmental & Social \\
\hline 513 & Lee et al. & 2014 & $\begin{array}{l}\text { The role of the state as an inter-scalar } \\
\text { mediator in globalizing liquid crystal } \\
\text { display industry development in South } \\
\text { Korea }\end{array}$ & $\mathrm{HI}$ & $\mathrm{CP}$ & $\uparrow$ & & \\
\hline 517 & Athukorala & 2014 & $\begin{array}{l}\text { Growing with global production } \\
\text { sharing: The tale of Penang export hub, } \\
\text { Malaysia }\end{array}$ & UM & $\mathrm{CP}$ & $\uparrow$ & & \\
\hline 519 & Liu et al. & 2013 & $\begin{array}{l}\text { Strategic coupling of local firms in } \\
\text { global production networks: The rise of } \\
\text { the home appliance industry in } \\
\text { Shunde, China }\end{array}$ & UM & $\mathrm{CP}$ & $\uparrow$ & & \\
\hline 523 & Kleibert & 2014 & $\begin{array}{l}\text { Strategic coupling in 'next wave cities': } \\
\text { Local institutional actors and the } \\
\text { offshore service sector in the Philippines }\end{array}$ & LM & $S$ & $\uparrow$ & & \\
\hline 527 & Yang & 2011 & $\begin{array}{l}\text { State-led technological innovation of } \\
\text { domestic firms in Shenzhen, China: } \\
\text { Evidence from liquid crystal display } \\
\text { (LCD) industry }\end{array}$ & UM & $\mathrm{CP}$ & $\uparrow$ & & \\
\hline 530 & Hsu & 2011 & $\begin{array}{l}\text { State Transformation and Regional } \\
\text { Development in Taiwan: From } \\
\text { Developmentalist Strategy to Populist } \\
\text { Subsidy }\end{array}$ & $\mathrm{HI}$ & & $\uparrow$ & & \\
\hline 604 & Riain & 2004 & $\begin{array}{l}\text { The politics of mobility in technology- } \\
\text { driven commodity chains: } \\
\text { Developmental coalitions in the Irish } \\
\text { software industry }\end{array}$ & $\mathrm{HI}$ & $S$ & $\uparrow$ & & \\
\hline 623 & Paus, Gallagher & 2008 & $\begin{array}{l}\text { Missing links: Foreign investment and } \\
\text { industrial development in Costa Rica } \\
\text { and Mexico }\end{array}$ & UM & $\mathrm{CP}$ & $\uparrow \square$ & & \\
\hline 624 & $\begin{array}{l}\text { Rutherford, } \\
\text { Holmes }\end{array}$ & 2008 & $\begin{array}{l}\text { The flea on the tail of the dog': Power } \\
\text { in global production networks and the } \\
\text { restructuring of Canadian automotive } \\
\text { clusters }\end{array}$ & $\mathrm{HI}$ & $\mathrm{CP}$ & $\uparrow \square$ & & \\
\hline 625 & Smith et al. & 2008 & $\begin{array}{l}\text { Reconfiguring 'post-socialist' regions: } \\
\text { Cross-border networks and regional } \\
\text { competition in the Slovak and } \\
\text { Ukrainian clothing industry }\end{array}$ & $\mathrm{HI}$ & TM & $\square$ & & \\
\hline 627 & Felker & 2009 & $\begin{array}{l}\text { The political economy of Southeast } \\
\text { Asia's techno-glocalism }\end{array}$ & UM & & $\uparrow \square$ & & \\
\hline 636 & Ernst & 2010 & $\begin{array}{l}\text { Upgrading through innovation in a } \\
\text { small network economy: Insights from } \\
\text { Taiwan's IT industry }\end{array}$ & $\mathrm{HI}$ & $\mathrm{CP}$ & $\uparrow \square$ & & \\
\hline 637 & Chen & 2010 & $\begin{array}{l}\text { Global Production Network and the } \\
\text { Upgrading of China's Integrated Circuit } \\
\text { Industry }\end{array}$ & UM & $\mathrm{CP}$ & $\uparrow \square$ & & \\
\hline
\end{tabular}

Note When blank, it means that the policy initiative was not tackling any specific industry and or information on upgrading are not reported $H I$ high income, UM upper-middle income, $L M$ lower-middle income, $L I$ low income, $T M$ traditional manufacturing, NRB natural resource-based, $C P$ complex products, $S$ service; $\uparrow$ upgrading, $\square$ downgrading or no-upgrading 
Table A.2 Landmark publications on GVCs from international organizations

\begin{tabular}{lll}
\hline International & Year & Title \\
Organisation & & \\
\hline World Bank & 2010 & Global Value Chains in a Postcrisis World \\
& 2016 & Making Global Value Chains Work for Development \\
& 2019 & World Development Report, The Changing Nature of Work \\
& 2020 & Trading For Development in the Age of GVCs \\
WTO & 2011 & Trade patterns and GVCs in East Asia: from trade in goods to trade in tasks \\
& 2013 & Global value chains in a changing world \\
OECD/WTO & 2013 & Aid for Trade at a glance: connecting to value chains \\
OECD/WTO/World & 2019 & Aid for Trade at a glance: economic diversification and empowerment \\
Bank & 2014 & GVCs: Challenges, opportunities and implications for policy \\
& 2017 & Measuring and Analysing the impact of GVCs on Economic Development \\
& 2019 & GVC Development Report: technological innovation, supply chain trade and workers in a globalised \\
UNCTAD & world \\
& 2013 & World Investment Report \\
UNIDO & 2017 & World Investment Report \\
& 2020 & World Investment Report \\
& 2002 & Innovation and Learning in Global Value Chains \\
& 2011 & Diagnostics for Industrial VC Development: An Integrated Tool \\
& 2015 & GVCs and Development: UNIDO's Support towards Inclusive and Sustainable Industrial \\
& Development \\
& 2006 & Decent work in the global economy: a research strategy \\
& 2015 & Value Chain Development For Decent Work \\
\hline
\end{tabular}

state policies, suggesting good practice that should inform every policy maker, irrespective of the type of state role played in relation to GVCs.

Our analysis highlights that developing effective GVC-oriented policies is a demanding task, which requires in-depth understanding of coordinated, cross-border production that differentiate GVCs from other types of industrial organization (Mayer \& Gereffi, 2019). Building on recent acknowledgement that states matter in GVCs (Horner \& Alford, 2019), we have provided a systematic account of how they matter from a policy perspective, as demonstrated through our discussion under the facilitator, regulator, producer, and buyer roles.

Strategies were implemented to address the most significant sources of bias found in systematic literature reviews, particularly regarding sampling, selecting, and expectancy bias (Durach et al., 2017). Nonetheless, we acknowledge the study has some limitations worth noting when interpreting the results. First, our analysis is based on policies already identified and discussed within the academic literature, and therefore cannot provide a complete account of all initiatives undertaken at the global level. Second, the analysis drew solely from English language-based articles - the most common language for academic publications on the topic. Third, while accounting for seminal contributions from the gray literature, the present analysis was only able to scratch the surface of what is a vast body of IO publications. While we are aware our methodological approach is not free of limitations (see e.g., Durach et al., 2017), we have worked hard to overcome the most significant pitfalls and maximize the benefits of such a review, resulting in a rigorously developed and non-subjective overview of the literature.

Based on our analysis, it is clear that states have a central role to play in mediating GVCs and capturing the social, economic, and environmental gains from domestic firm and industry engagement. Yet, it is also clear that governments require a multiscalar appreciation of wider commercial GVC dynamics, working with multiple (and sometimes competing) stakeholders to achieve their developmental objectives. There is little doubt that understanding and informing effective state policy in an era of GVCs is an increasingly active research agenda, and one that can and should continue to be co-developed with the academic community. 


\section{ACKNOWLEDGEMENTS}

The authors would like to thank Umberto Velluso, University of Padova, for his support on data elaboration and the participants to the JIBP Paper Development Workshop at ElBA2019, the guest editors, and the anonymous referees for precious feedback on previous versions of this manuscript.

\section{FUNDING}

Open access funding provided by Università degli Studi di Padova within the CRUI-CARE Agreement.

\section{NOTES}

${ }^{1}$ While acknowledging the important differences across GVCs and GPNs literatures (see Bair, 2009 for a broader discussion), in this context we consider both as synonymous, given similarities in how the state is conceived (Horner, 2017; Smith, 2015). While it was not initially at the center of GVC theorization - which rather focused more on private governance (Smith, 2015) - it has been one of the pillars considered in subsequent GVC analyses, as supported by the systematic review of the GVCs literature by De Marchi et al. (2020). The state and, more generally, the institutional context of global production, have been a more predominant element in the GPN literature, which has highlighted the 'strategic coupling' in the agency and resources of local institutions and of multinationals grounded in that locality (Coe et al., 2004; Yeung, 2009).

${ }^{2}$ In relation to environmental upgrading, Krishnan (2017) and De Marchi et al., (2019) distinguish between upgrading as process and outcomes. In this paper, we refer specifically to upgrading outcomes; i. e., the policies that are associated with improved economic results and/or social or environmental conditions.

${ }^{3}$ Following Horner (2017) and Wade (2016), this paper adopts the term 'GVC-oriented policies' to refer to all policies that have been developed taking into account the specificities of the GVC, including those that might, even unintentionally, impact on firms'

\section{REFERENCES}

Abdulsamad, A., \& Manson, H. 2019. Public-private partnerships in global value chains. In S. Ponte, G. Gereffi, \& G. RajReichert (Eds), Handbook on global value chains: 537-554. Cheltenham, UK: Edward Elgar Publishing. ability to participate in, and appropriate value from, GVCs.

${ }^{4}$ The systematic literature review was conducted up to and including 2019. This was the last full year that the authors' were able to examine at the time the review took place. Publications from 2020 onward are therefore not included.

${ }^{5}$ The article is informed and framed by a much larger number of contributions, including those that are solely theoretical. However, given the scope and aims of the systematic review, only contributions that met the conditions summarized in Figure 1 are included in the empirical analysis that follows.

${ }^{6}$ Here and in the following discussion, we refer to the World Bank classification of countries for the 2020 fiscal year, which distinguish among high, uppermiddle, lower-middle, low-income countries. The full list is available here: https://datahelpdesk.worldbank. org/knowledgebase/articles/906519-world-bank-

country-and-lending-groups. For the classification of industries, we draw on Giuliani et al. (2005), who distinguish between traditional manufacturing, natural resource-based, complex products and services industries. See also Table A.2 in the Appendix.

${ }^{7}$ Pietrobelli and Staritz (2018) consider social and environmental conditions under the 'broader objectives' definition. Here, social conditions refer to what the authors' term 'poverty reduction', 'quality of employment' and 'gender quality'.

${ }^{8}$ Following Gereffi (2019) and Mayer and Gereffi (2019), we considered as relevant International Organizations (IOs): ILO, WTO, OECD, World Bank, UNCTAD, and UNIDO.

${ }^{9}$ The full list of publications is available in Table A.2 in the Appendix.

${ }^{10}$ Please note that not all papers had enough information to classify the specific type of economic upgrading.

${ }^{11}$ While it falls outside the scope of this article, it is important to highlight that such a heterogeneous impact of policies is also connected with the different endowment of firms' resources and capabilities, as discussed in the final section of this paper.

Aberg, J. H. S., \& Becker, D. 2019. The world is more than a stage: Foreign policy, development and spatial performativity in Ethiopia. Territory, Politics, Governance, 0: 1-16.

Alam, M. S., \& Natsuda, K. 2016. The competitive factors of the Bangladeshi garment industry in the post-MFA era. Canadian Journal of Development Studies, 37: 316-336. 
Alford, M. 2016. Trans-scalar embeddedness and governance deficits in global production networks: Crisis in South African fruit. Geoforum, 75: 52-63.

Alford, M., \& Phillips, N. 2018. The political economy of state governance in global production networks: Change, crisis and contestation in the South African fruit sector. Review of International Political Economy, 25: 98-121.

Athukorala, P. C. 2014. Growing with global production sharing: The tale of Penang export hub, Malaysia. Competition and Change, 18: 221-245.

Athukorala, P. C. 2017. Global productions sharing and local entrepreneurship in developing countries: Evidence from Penang export hub, Malaysia. Asia and the Pacific Policy Studies, 4: 180-194.

Azmeh, S. 2014a. Trade regimes and global production networks. Geoforum, 57: 57-66.

Azmeh, S. 2014b. Labour in global production networks: Workers in the qualifying industrial zones (QIZs) of Egypt and Jordan. Global Networks, 14: 495-513.

Azmeh, S. 2015. Transient global value chains and preferential trade agreements: Rules of origin in US trade agreements with Jordan and Egypt. Cambridge Journal of Regions, Economy and Society, 8: 475-490.

Bair, J. 2009. Global commodity chains: genealogy and review. In J. Bair (Ed), Frontiers of global commodity chains. Palo Alto: Stanford University Press.

Bair, J., \& Gereffi, G. 2001. Local clusters in global chains: The causes and consequences of export dynamism in Torreon's blue jeans industry. World Development, 29: 1885-1903.

Barrientos, S., Gereffi, G., \& Rossi, A. 2011a. Economic and social upgrading in global production networks: A new paradigm for a changing world. International Labour Review, 150: 319-340.

Barrientos, S., Mayer, F., Pickles, J., \& Posthuma, A. $2011 \mathrm{~b}$. Decent work in global production networks: Framing the policy debate. International Labour Review, 150: 297-317.

Băzăvan, A. 2019. Chinese government's shifting role in the national innovation system. Technological Forecasting and Social Change, 148: 119738.

Behuria, P. 2019. The domestic political economy of upgrading in global value chains: How politics shapes pathways for upgrading in Rwanda's coffee sector*. Review of International Political Economy, 0: 1-29.

Blažek, J. 2016. Towards a typology of repositioning strategies of GVC/GPN suppliers: The case of functional upgrading and downgrading. Journal of Economic Geography, 16: 849-869.

Braun-Munzinger, C. 2019. Chinese CSR standards and industrial policy in GPNs. Critical Perspectives on International Business, 16: 165-185.

Buckley, P. J. 2004. Government policy responses to strategic rent-seeking transnational firms. Transnational Corporations, 5: $1-17$.

Buckley, P. J., \& Ghauri, P. N. 2004. Globalisation, economic geography and the strategy of multinational enterprises. Journal of International Business Studies, 35: 81-98.

Butollo, F., \& Ten Brink, T. 2018. A great leap? Domestic market growth and local state support in the upgrading of China's LED lighting industry. Global Networks, 18: 285-306.

Cattaneo, O., Gereffi, G., Miroudot, S., \& Taglioni, D. (2013). Joining, upgrading and being competitive in global value chains: A strategic framework. World Bank Policy Research Working Paper 6406. Washington DC: The World Bank.

Chalaby, J. K. 2017. Can a GVC-oriented policy mitigate the inequalities of the world media system? Strategies for economic upgrading in the TV format global value chain. International Journal of Digital Television, 8: 9-28.

Chen, L., \& Xue, L. 2010. Global production network and the upgrading of China's integrated circuit industry. China and World Economy, 18: 109-126.
Coe, N., Dicken, P., \& Hess, M. 2008. Global production networks: Realizing the potential. Journal of Economic Geography, 8: 271-295.

Coe, N., Hess, M., Yeung, H. W., Dicken, P., \& Henderson, J. 2004. "Globalizing" regional development: A global production networks perspective. Transactions of the Institute of British Geographers, 29: 468-484.

Curran, L., Nadvi, K., \& Campling, L. 2019. The influence of tariff regimes on global production networks (GPNs). Journal of Economic Geography, 19: 873-895.

Dallas, M. P. P., Ponte, S., \& Sturgeon, T. J. J. 2019. Power in global value chains. Review of International Political Economy, 26: 666-694.

Dannenberg, P., Diez, J. R., \& Schiller, D. 2018. Spaces for integration or a divide? New-generation growth corridors and their integration in global value chains in the Global South. Zeitschrift Fur Wirtschaftsgeographie, 62: 135-151.

De Marchi, V., Di Maria, E., Golini, R., \& Perri, A. 2020. Nurturing International Business research through Global Value Chains literature: A review and discussion of future research opportunities. International Business Review, 29: 1017085.

De Marchi, V., Di Maria, E., Krishnan, A., \& Ponte, S. 2019. Environmental upgrading in global value chains. In S. Ponte, G. Gereffi, \& G. Raj-Reichert (Eds), Handbook on global value chains: 310-323. Cheltenham: Edward Elgar Publishing.

Defraigne, J. C. 2017. Chinese outward direct investments in Europe and the control of the global value chain. Asia Europe Journal, 15: 213-228.

Dermawan, A., \& Hospes, O. 2018. When the state brings itself back into GVC: The case of the Indonesian Palm Oil Pledge. Global Policy, 9: 21-28.

Dong, M., \& He, J. 2018. Linking the past to the future: A reality check on cross-border timber trade from Myanmar (Burma) to China. Forest Policy and Economics, 87: 11-19.

Durach, C. F., Kembro, J., \& Wieland, A. 2017. A new paradigm for systematic literature reviews in supply chain management. Journal of Supply Chain Management. https://doi.org/10.1111/ jscm.12145.

Durán, C. R. 2019. Globalization and the scrambling process of catching up in Mexico. Seoul Journal of Economics, 32: 83-106.

Elms, D. K., \& Low, P., (Eds.), (2013). Global value chains in a changing world. Geneva: World Trade Organization.

Feenstra, R. C. 1998. Integration of trade and disintegration of production in the global economy. Journal of Economic Perspectives, 12: 31-50.

Felker, G. 2009. The political economy of Southeast Asia's techno-glocalism. Cambridge Review of International Affairs. https://doi.org/10.1080/09557570903104016.

Fernandez-Stark, K., \& Gereffi, G. 2019. Global value chain analysis: a primer (second edition). In S. Ponte, G. Gereffi, \& G. Raj-Reichert (Eds), Handbook on global value chains: 54-76. Cheltenham, UK: Edward Elgar Publishing.

Frederick, S. 2019. Global value chain mapping. In S. Ponte, G. Gereffi, \& G. Raj-Reichert (Eds), Handbook on global value chains: 29-53. Cheltenham, UK: Edward Elgar Publishing.

Frederick, S., \& Staritz, C. 2011. Apparel industry developments in the Global Apparel Industry after the MFA phaseout. In G. C. Lopez-Acevedo \& R. Robertson (Eds), Sewing success? Employment and wage effect of the end of the Multi-fibre Arrangement (MFA). (Vol. I). Washington, DC: World Bank Publications. https://doi.org/10.1596/9780821387788_ch03.

Gao, B., Dunford, M., Norcliffe, G., \& Liu, W. 2019. Governance capacity, state policy and the rise of the Chongqing notebook computer cluster. Area Development and Policy, 4: 321-345.

Gereffi, G. 1994. The organization of buyer-driven global commodity chains: How US retailers shape overseas production networks. In G. Gereffi \& M. Korzeniewicz (Eds), Commodity chains and global capitalism (Praeger).: 95-122. Westport: Praeger. 
Gereffi, G. 1999. International trade and industrial upgrading in the apparel commodity chain. Journal of International Economics, 48: 37-70.

Gereffi, G. 2005. The global economy: Organization, governance, and development. The Handbook of Economic Sociology, 2: $160-182$.

Gereffi, G. 2014. Global value chains in a post-Washington Consensus world. Review of International Political Economy, 21: 9-37.

Gereffi, G. 2018. Global Value Chains And Development. Cambridge: Cambridge University Press. https://doi.org/10.1017/ 9781108559423.

Gereffi, G. 2019. Global value chains and international development policy: Bringing firms, networks and policy-engaged scholarship back in. Journal of International Business Policy, 116.

Gereffi, G., Humphrey, J., \& Sturgeon, T. 2005. The governance of global value chains. Review of International Political Economy, 12: 78-104.

Gereffi, G., \& Lee, J. 2016. Economic and social upgrading in global value chains and industrial clusters: Why governance matters. Journal of Business Ethics, 133: 25-38.

Gereffi, G., \& Sturgeon, T. 2013. Global value chain-oriented industrial policy: the role of emerging economies. In D. K. Elms \& P. Low (Eds), Global value chains in a changing world: 329-360. Geneva: WTO Publications.

Giuliani, E., De Marchi, V., \& Rabellotti, R. 2017. Do global value chains offer developing countries learning and innovation opportunities? European Journal of Development Research, 119.

Giuliani, E., Pietrobelli, C., \& Rabellotti, R. 2005. Upgrading in global value chains: Lessons from Latin American clusters. World Development, 33: 549-573.

Guerrieri, P., \& Pietrobelli, C. 2004. Industrial districts' evolution and technological regimes: Italy and Taiwan. Technovation, 24: 899-914.

Henderson, J., Dicken, P., Hess, M., Coe, N., \& Yeung, H.W.-C. W.-C. 2002. Global production networks and the analysis of economic development. Review of International Political Economy, 9: 436-464.

Horner, R. 2017. Beyond facilitator? State roles in global value chains and global production networks. Geography Compass, 11: e12307.

Horner, R., \& Alford, M. 2019. The roles of the state in global value chains. In S. Ponte, G. Gereffi, \& G. Raj-Reichert (Eds), Handbook on global value chains: 555-569. Cheltenham, UK: Edward Elgar Publishing.

Hossain, N. 2019. Rana Plaza, disaster politics, and the empowerment of women garment workers in Bangladesh. Contemporary South Asia, 27: 516-530.

Hsu, J. Y. 2011. State transformation and regional development in Taiwan: From developmentalist strategy to populist subsidy. International Journal of Urban and Regional Research, 35: 600619.

Hughes, A., Morrison, E., \& Ruwanpura, K. N. 2019. Public sector procurement and ethical trade: Governance and social responsibility in some hidden global supply chains. Transactions of the Institute of British Geographers, 44: 242-255.

Humphrey, J., \& Schmitz, H. 2002. How does insertion in global value chains affect upgrading in industrial clusters? Regional Studies, 36: 1017-1027.

ILO. 2015. Value chain development for decent work. How to create employment and improve working conditions in targeted sectors. Value Chain Development for Decent Work.

IILS. (2006). 'Decent work in a global economy: $A$ research strategy,'. International Institute for Labour Studies. Accessed 14 Dec 2020. http://www.ilo.org/wcmsp5/groups/public/— dgreports/_inst/documents/genericdocument/wcms_ 192590.pdf.

Kaplinsky, R. 2014. Shudder: The challenges to "industrial policies" in the early 21 st century in low-and middle-income economies. International Business and Sustainable Development, 69-90.

Kaplinsky, R., \& Morris, M. 2001. A handbook for value chain research. Report Prepared for IDRC.

Kaplinsky, R., \& Morris, M. 2016. Thinning and thickening: Productive sector policies in the era of global value chains. European Journal of Development Research, 28: 625-645.

Kergroach, S. 2019. National innovation policies for technology upgrading through GVCs: A cross-country comparison. Technological Forecasting and Social Change, 145: 258-272.

Kleibert, J. M. 2015. Industry-academe linkages in the Philippines: Embedding foreign investors, capturing institutions? Geoforum, 59: 109-118.

Klooster, D., \& Mercado-Celis, A. 2016. Sustainable production networks: Capturing value for labour and nature in a furniture production network in Oaxaca, Mexico. Regional Studies, 50: 1889-1902.

Krishnan, A. 2017. Re-thinking the environmental dimensions of upgrading and embeddedness in production networks: The case of Kenyan horticulture farmers. Manchester: University of Manchester.

Lee, J., \& Gereffi, G. 2015. Global value chains, rising power firms and economic and social upgrading. Critical Perspectives on International Business, 11(3/4): 319-339.

Liberati, A., Altman, D. G., Tetzlaff, I., Mulrow, C., Gøtzsche, P. C., et al. 2009. The PRISMA statement for reporting systematic reviews and meta-analyses of studies that evaluate health care interventions: Explanation and elaboration. Journal of Clinical Epidemiology, 62: 1-34.

Liu, Y., \& Yang, C. 2013. Strategic coupling of local firms in global production networks: The rise of the home appliance industry in Shunde, China. Eurasian Geography and Economics. https://doi.org/10.1080/15387216.2014.883286.

Markiewicz, O. 2019. Stuck in second gear? EU integration and the evolution of Poland's automotive industry. Review of International Political Economy, 0: 1-23.

Martin-Ortega, O., \& O'Brien, C. M. 2017. Advancing respect for labour rights globally through public procurement. Politics and Governance, 5: 69-79.

Martinez-Covarrubias, J. L., Lenihan, H., \& Hart, M. 2017. Public support for business innovation in Mexico: A cross-sectional analysis. Regional Studies, 51: 1786-1800.

Mayer, F., \& Gereffi, G. 2019. International development organizations and global value chains. In S. Ponte, G. Gereffi, \& G. Raj-Reichert (Eds), Handbook on global value chains: 570 584. Cheltenham, UK: Edward Elgar Publishing.

Mayer, F. W., \& Phillips, N. 2017. Outsourcing governance: States and the politics of a 'global value chain world.' New Political Economy. https://doi.org/10.1080/13563467.2016. 1273341.

Milberg, W., \& Winkler, D. 2011. Economic and social upgrading in global production networks: Problems of theory and measurement. International Labour Review, 150: 341-365.

Moazzem, K. G. K. G., \& Sehrin, F. 2016. Economic upgrading in Bangladesh's apparel value chain during the post-MFA period: An exploratory analysis. South Asia Economic Journal, 17: 73-93.

Morris, M., Plank, L., \& Staritz, C. 2016. Regionalism, end markets and ownership matter: Shifting dynamics in the apparel export industry in Sub Saharan Africa. Environment and Planning A: Economy and Space, 48: 1244-1265.

Morris, M., \& Staritz, C. 2019. Industrialization paths and industrial policy for developing countries in global value chains. In S. Ponte, G. Gereffi, \& G. Raj-Reichert (Eds), Handbook on global value chains: 506-520. Cheltenham, UK: Edward Elgar Publishing.

Morrison, A., Pietrobelli, C., \& Rabellotti, R. 2008. Global value chains and technological capabilities: A framework to study learning and innovation in developing countries. Oxford Development Studies, 36: 39-58. 
Mudambi, R., Li, L., Ma, X., Makino, S., Qian, G., et al. 2018. Zoom in, zoom out: Geographic scale and multinational activity. Journal of International Business Studies, 49: 929-941.

Ngo, C. N. 2017. Industrial development, liberalisation and impacts of Vietnam-China border trade. European Journal of East Asian Studies, 16: 154-184.

Paus, E. A., \& Gallagher, K. P. 2008. Missing links: Foreign investment and industrial development in Costa Rica and Mexico. Studies in Comparative International Development. https://doi.org/10.1007/s12116-007-9016-2.

Pavlínek, P. 2016. Whose success? The state-foreign capital nexus and the development of the automotive industry in Slovakia. European Urban and Regional Studies, 23: 571-593.

Pedersen, R. H., Mutagwaba, W., Jønsson, J. B., Schoneveld, G., Jacob, T., et al. 2019. Mining-sector dynamics in an era of resurgent resource nationalism: Changing relations between large-scale mining and artisanal and small-scale mining in Tanzania. Resources Policy, 62: 339-346.

Pickles, J., Plank, L., Staritz, C., \& Glasmeier, A. 2015. Trade policy and regionalisms in global clothing production networks. Cambridge Journal of Regions, Economy and Society, 8: 381-402.

Pietrobelli, C., \& Puppato, F. 2016. Technology foresight and industrial strategy. Technological Forecasting and Social Change, 110: 117-125.

Pietrobelli, C., \& Rabellotti, R. 2011. Global value chains meet innovation systems: Are there learning opportunities for developing countries? World Development, 39: 1261-1269.

Pietrobelli, C., \& Staritz, C. 2013. Challenges for global value chain interventions in Latin America. Inter-American Development Bank (IDB) Competitiveness and Innovation Division Technical Note.

Pietrobelli, C., \& Staritz, C. 2018. Upgrading, interactive learning, and innovation systems in value chain interventions. European Journal of Development Research, 30: 557-574.

Plank, L., \& Staritz, C. 2016. Social up- and downgrading of apparel workers in Romania: Fast fashion, post-socialist transformation, Europeanization, and the global economic crisis. Transfer: European Review of Labour and Research, 22: 233248.

Ponte, S., \& Ewert, J. 2009. Which way is "up" in upgrading? Trajectories of change in the value chain for South African Wine. World Development, 37: 1637-1650.

Rasiah, R., Kimura, F., \& Oum, S. 2016. Epilogue: Implications for promoting firm-level technological capabilities. Asia Pacific Business, Review, 22: 193-200.

Riain, S. O. 2004. The politics of mobility in technology-driven commodity chains: Developmental coalitions in the Irish software industry. International Journal of Urban and Regional Research. https://doi.org/10.1111/j.0309-1317.2004.00541. $x$.

Riisgaard, L., Lund-Thomsen, P., \& Coe, N. M. 2019. Multistakeholder initiatives in global production networks: Naturalizing specific understandings of sustainability through the Better Cotton Initiative. Global Networks, 1-26.

Rossi, A. 2015. Better work: Harnessing incentives and influencing policy to strengthen labour standards compliance in global production networks. Cambridge Journal of Regions, Economy and Society, 8: 505-520.

Rutherford, T., \& Holmes, J. 2007. "The flea on the tail of the dog": Power in global production networks and the restructuring of Canadian automotive clusters. Journal of Economic Geography, 8: 519-544.

Schouten, G., \& Hospes, O. 2018. Public and private governance in interaction: Changing interpretations of sovereignty in the field of Sustainable Palm Oil. Sustainability, 10: 17-20.
Smith, A. 2015. The state, institutional frameworks and the dynamics of capital in global production networks. Progress in Human Geography, 39: 290-315.

Smith, A., Barbu, M., Campling, L., Harrison, J., \& Richardson, B. 2018. Labor regimes, global production networks, and European Union Trade Policy: Labor standards and export production in the Moldovan Clothing Industry. Economic Geography, 94: 550-574.

Strange, R., \& Humphrey, J. 2018. What lies between market and hierarchy? Insights from internalization theory and global value chain theory. Journal of International Business Studies. https://doi.org/10.1057/s41267-018-0186-0.

Tessmann, J. 2020. Global value chains and policy practice: The making of linkages in the Ivorian cashew industry. Competition and Change, 24: 26-43.

Tewari, M. 2017. Relational contracting at the bottom of global garment value chains: Lessons from Mewat. Indian Journal of Labour Economics, 60: 137-154.

Tranfield, D., Denyer, D., \& Smart, P. 2003. Towards a methodology for developing evidence-informed management knowledge by means of systematic review*. British Journal of Management, 14: 207-222.

UNCTAD. 2020. World Investment Report.

UNIDO. 2015. GVCs and Development: UNIDO's Support towards Inclusive and Sustainable Industrial Development.

Wade, R. H. (2003). What strategies are viable for developing countries today? the world trade organization and the shrinking of "development space". Review of International Political Economy, 10(4), 621-644.

Wade, R. (2016). Industrial policy in response to the middleincome trap and the third wave of the digital revolution. Global Policy, 7, 469-480.

Wentink, C. R., Raemaekers, S., \& Bush, S. R. 2017. Cogovernance and upgrading in the South African small-scale fisheries value chain. Maritime Studies, 16: 5 .

Whitfield, L., \& Staritz, C. 2020. Local supplier firms in Madagascar's apparel export industry: Upgrading paths, transnational social relations and regional production networks. Environment and Planning A. https://doi.org/10.1177/ $0308518 \times 20961105$.

Whitfield, L., Staritz, C., \& Morris, M. 2020. Global value chains, industrial policy and economic upgrading in Ethiopia's apparel sector. Development and Change. https://doi.org/10.1111/ dech. 12590.

Trading for development in the age of global value chains. World Development Report 2020.

WTO, IDE-JETRO, OECD, VIBE, \& World Bank. 2019. Global value chain development report 2019: Technological innovation, supply chain trade, and workers in a globalized world. Washington, DC: World Bank Group.

Yang, C. 2014. State-led technological innovation of domestic firms in Shenzhen, China: Evidence from liquid crystal display (LCD) industry. Cities, 38: 1-10.

Yeung, G. 2019. 'Made in China 2025': The development of a new energy vehicle industry in China. Area Development and Policy, 4: 39-59.

Yeung, H. W. 2009. Regional development and the competitive dynamics of global production networks: An East Asian perspective. Regional Studies, 43: 325-351.

Yoshida, N. 2017. Local institutions and global value chains. Journal of Agribusiness in Developing and Emerging Economies, 7: $318-338$.

Zhu, X. 2015. Demystifying the role of Chinese commercial actors in shaping China's Foreign assistance: The case of postwar Sri Lanka. Stability, 4: 1-18. 


\section{APPENDIX A}

\begin{abstract}
ABOUT THE AUTHORS
Valentina De Marchi is Associate Professor at the University of Padova, Italy, Department of Economics and Management. She is interested in environmental innovations and circular economy and local development in the context of global value chains. She is the president of the GRONEN association, Italian representative at the European International Business Academy (EIBA), and member of the organizing committee of Network $\mathrm{O}$ (Global Value Chains) within SASE.
\end{abstract}

Matthew Alford is Senior Lecturer in International Business and Management at the Alliance Manchester Business School, University of Manchester. His research addresses questions of development in the context of globalization, transnational trading networks, and labor, with a special focus on the role of nation states and of labor agency, and the evolving strategies adopted by workers in contesting their conditions.
Open Access This article is licensed under a Creative Commons Attribution 4.0 International License, which permits use, sharing, adaptation, distribution and reproduction in any medium or format, as long as you give appropriate credit to the original author(s) and the source, provide a link to the Creative Commons licence, and indicate if changes were made. The images or other third party material in this article are included in the article's Creative Commons licence, unless indicated otherwise in a credit line to the material. If material is not included in the article's Creative Commons licence and your intended use is not permitted by statutory regulation or exceeds the permitted use, you will need to obtain permission directly from the copyright holder. To view a copy of this licence, visit http://creativecommons.org/licenses/by/4.0/.

Publisher's Note Springer Nature remains neutral with regard to jurisdictional claims in published maps and institutional affiliations.

Accepted by Roberta Rabellotti, Guest Editor, 8 March 2021. This article has been with the authors for five revisions. 